\title{
Chapter 2 \\ The current debate: \\ Galilee versus Jerusalem in Mark's story of Jesus
}

\subsection{INTRODUCTION}

The purpose of this chapter is twofold: First, to give a review of the past and present debate in regard to the (political) opposition between Galilee and Jerusalem in the Gospel of Mark. Second, to identify the research gaps in this debate which then will be used as a starting point for an analysis of Galilee and Jerusalem as political settings in Mark's story of Jesus.

To review the past and present scholarship in regard to the opposition between Galilee and Jerusalem in Mark's story of Jesus, the following scheme is selected ${ }^{1}$ : First, the studies that used a historical-critical approach to analyze the opposition between Galilee and Jerusalem in the Gospels are discussed (section 2.2), then studies that used a literary-critical approach to analyze this opposition in Mark's story of Jesus (section 2.3), and finally, ideological-critical studies are taken into consideration $(2.4)^{2}$.

In section 2.2 it will be indicated that historical-critical studies of the opposition between Galilee and Jerusalem were motivated by a historical concern in regard to the composition of Mark's gospel. They yielded the result that a theological, eschatological and geographical opposition, historically and socially speaking, may have existed between the centers of Galilee and Jerusalem in the time of Mark's writing of the Gospel. These scholars' work served as a stimulus for the literary-critical studies of space in Mark's gospel (section 2.3). By taking more seriously Mark as literary text, these scholars indicated that the central spatial designation in Mark is that of the way of Jesus, a way that can be depicted as a way of suffering. Finally, in section 2.4 it will be indicated that the ideological-critical studies of Belo, Myers and Waetjen, although not explicitly concentrating on space in Mark's story of Jesus, translated Jesus' way, as well as the opposition between Galilee and Jerusalem in Mark into social terms: Jesus' way was a way of suffering, because of a political opposition between Galilee and Jerusalem in the Gospel.

In section 2.5 the current debate (described in sections 2.2 to 2.4 ) will be evaluated. From this evaluation (in section 2.5), research gaps will be identified. The research gaps identified will then serve as the point of departure for a study of Galilee and Jerusalem as (political) settings (focal space/symbols; see section 3.4 for the meaning of this term) in Mark's story of Jesus. 


\subsection{GALILEE VERSUS JERUSALEM IN MARK: A THEOLOGICAL CON- FLICT}

\subsubsection{Galilee versus Jerusalem: The historical-critical period}

As has been indicated in section 1.1, Lohmeyer $(1936,1942)$ was the first New Testament scholar who identified an opposition between Galilee and Jerusalem in the Gospel of Mark. As will be indicated in sections 2.2.1.1 to 2.2.1.4, Lohmeyer's insight in this regard was taken up by scholars such as Lightfoot (1936), Marxsen (1959) and Kelber (1974). In a previous article (see Van Eck 1988:139-163), it was indicated that this insight of Lohmeyer influenced Lightfoot's, Marxsen's and Kelber's own understanding of the opposition between Galilee and Jerusalem in such a manner that it is also possible to speak of the Lohmeyer - Lightfoot - Marxsen - Kelber chain in regard to the study of the opposition between Galilee and Jerusalem in Mark.

This then will also be the sequence in which these scholars' understanding of the opposition between Galilee and Jerusalem in Mark will be discussed in section 2.2 (i e sections 2.2.1.1 to 2.2.1.4). In these subsections it will also be indicated that, accept for the fact that Lightfoot, Marxsen and Kelber all build on the insight of Lohmeyer, in general these studies all have in common the fact that they were motivated by a historical concem in connection with the composition of Mark's gospel. In section 2.2.2, a summary of the historical-critical approach towards the opposition between Galilee and Jerusalem in Mark will be given. A few critical questions will also be posed in section 2,5 with the aim of helping to identify the research gaps in the current debate in regard to the opposition between Galilee and Jerusalem in Mark's gospel.

\subsubsection{E Lohmeyer}

Historically speaking, Lohmeyer maintained in Galiläa und Jerusalem (1936) that early Christianity in Palestine had two main centers: Galilee and Jerusalem. In Galilee, a Son of Man eschatology predominated, and in Jerusalem a nationalistic messianic hope prevailed. Because of this historical opposition, Lohmeyer (1936:162-166) contended that this opposition may also be characterized theologically or christologically: In Galilee the basic presupposition about Jesus was that he was Lord, and in Jerusalem that Jesus was the Christ/Messiah. Galilee celebrated the breaking of the bread and Jerusalem the memorial meal. For Lohmeyer therefore, geography in Mark becomes theology. Galilee is the sphere of redemption, the center of Jesus' ministry and the sphere of divine activity, whereas Jerusalem is the sphere of hate, misunderstanding, opposition to Jesus and disaster. Galilee, however, is also the future center of Jesus' fulfilled kingdom, according to Mark 14:28 and 16:7. 
According to Lohmeyer, a distinct opposition between Galilee and Jerusalem can thus be indicated in the Gospel. Galilee is the center of Jesus ministry, and Jenusalem is the center of opposition towards the Markan Jesus. In his later work, titled Kultus und Evangelium, Lohmeyer (1942:106) described this opposition between Galilee and Jerusalem in terms of the concepts Evangelium (Galilee) and Kultus (Jerusalem). Jesus' activity in Galilee, in terms of the forgiving of sins, eating with sinners, disobeying the rules of the sabbath and fasting must be seen as creating conflict aimed at the cult in Jenusalem. Through this activity of Jesus he postulated a 'neue Heiligkeit und neues Heil' (Lohmeyer 1942:106) and also dismantled the cult in Jerusalem. In the activity of Jesus, Jerusalem is therefore replaced by Galilee, and the traditional 'Gottesstadt' by the new 'kommende Gotteshaus' (Lohmeyer 1942:109-110). Because Mark's gospel was written in Galilee where a community of believers existed from the beginning, Galilee is depicted as positive and Jerusalem as negative. Therefore, they can be seen as two opposing geographical, theological (and political) centers.

\subsubsection{R H Lightfoot}

Lightfoot (1938:1-48, 132-159) applied Lohmeyer's thesis particularly to the problem of understanding the conclusion of Mark's gospel. Using the Formgeschichte as historical-critical tool, Lightfoot (1938:1-48) argued that on the basis of both form (literary and philological grounds) and content (theological grounds) the Gospel was meant to end at Mark 16:8. According to Lightfoot (1938:44-48), however, the significance of this ending is made most clear by the theological opposition of Galilee and Jerusalem throughout the Gospel.

In regard to this opposition Lightfoot (1938:123) notes that the contents of the last part of Mark's gospel (on the way to Jerusalem and in Jerusalem) and that of the first

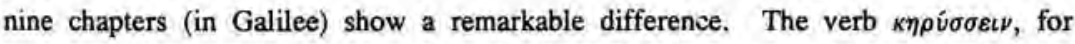
example, occurs only in the first nine chapters of Mark, as is also the case with Jesus' charge to secrecy. In contrast, in the last part of the Gospel we find no invitation to repentance and also no charge to secrecy. Further, 'many characteristic features of the Galilean ministry are either altogether absent or at least much less conspicuously present in the latter part of the Gospel' (Lightfoot 1938:123). Only two acts of power (miracle stories) and one parable are recorded in the Jerusalem-part of the Gospel, a parable which is also understood by those to whom it is addressed, as was not the case in Mark 4. The exorcisms of the unclean spirits also cease to exist in the latter part of the Gospel. Commenting on these characteristics in Mark, Lightfoot (1938:124-125) summarizes the opposition between Galilee and Jerusalem in Mark as follows: 
Galilee and Jerusalem therefore stand in opposition to each other .... The despised and ... outlawed Galilee is sh[o]wn to have been chosen by God as the seat of the gospel and the revelation of the Son of man, while the sacred city of Jenusalem, the home of [J]ewish piety and patriotism, has become the center of relentless hostility and sin. Galilee is the sphere of revelation, Jerusalem the scene of only rejection.

(Lightfoot 1938:124-125)

\subsubsection{W Marxsen}

Lohmeyer and Lightfoot's study of the opposition between Galilee and Jerusalem in Mark was further developed by Marxsen in his redaktionsgeschichtliche study of the Gospel of Mark. Marxsen shared the historical and eschatological emphases of Lohmeyer and Lightfoot but criticizes both for overlooking the importance of distinguishing between tradition and redaction in Mark. According to Marxsen, the focus in studying the spatial relations in Mark must be on the evangelist's redactional activity. The reason for this is the fact that the redaction in Mark is basically found in the framework of the Gospel, and that this framework, although geographical or 'topical' in expression, is theological in intent. Marxsen further held the opinion that the center of this theological framework is Galilee. Also, 'almost all references to place (except for Galilee) are already anchored in the tradition' (Marxsen 1959:62), and thus are not particularly important for understanding the intent of the Evangelist. Mark, however, inserted Galilee as the place of Jesus' activity in all his redactional remarks (cf Mk 1:7, $9,14,15,16,28,39 ; 3: 7-8)$. Galilee is therefore the center for the Markan Jesus as it was the center of the Markan community, and also will be the gathering place for awaiting the imminent parousia (cf Mk 14:28: 16:7). Thus, Mark writes a 'Galilean Gospel' (Marxsen 1959:92), 'Galilee is Jesus' place' (Marxsen 1959:59) and Jesus' 'decisive preaching always occurs in Galilee' (Marxsen 1959:62).

As Galilee was for Lohmeyer (1942:110) the 'Gotteshaus' of Jesus, such is the

case for Marxsen: 'Galilee is thus Jesus' 'home' in a far deeper sense than the merely historical. It is the place were he worked ... he is now working, and will work at his Parousia' (Marxsen 1959:94). Galilee, as a topographical setting, thus not only reflects something of the Sitz im Leben of the Markan community, but also something of the theological intent of Mark. Because Marxsen, in working out his ideas exegetically, attended almost exclusively to Galilee as a 'terra Christiana' where the parousia is awaited, the conclusion must not be made that the opposition between Galilee and Jerusalem, so explicitly stressed by Lohmeyer and Lightfoot, is apparently not of any theological importance for Marxsen. Rather, in concentrating mainly on Galilee, this 
opposition is implicitly stressed and taken into consideration. To put it in Marxsen own words: 'Galilee is obviously the evangelist's own creation. Mark does not intend to say: Jesus worked in Galilee, but rather: Where Jesus worked, there is Galilee' (Marxsen 1959:93). By stressing the importance of Galilee, against the 'unimportance' of Jerusalem, the opposition between Galilee versus Jerusalem, as was the case with Lohmeyer and Lightfoot, therefore is actually still of great importance for Marxsen (For a more detailed summary of Marxsen's contribution, see also Kealy 1982:160165; Malbon 1982:242-255; Van Eck 1984:4-19; 1988:142-148.)

\subsubsection{W H Kelber}

Kelber (1974), according to Malbon (1982;245), redresses the balance between the opposition of Galilee and Jerusalem in Mark by further strengthening the prevailing conception of Galilee by an exegesis of the so called 'kingdom passages' in Mark (cf inter alia Mk $1: 15 ; 3: 31-35 ; 4 ; 10-34 ; 8: 34-9: 1)$. On the grounds of his exegesis of these passages, Kelber (1974:64-65) not only agrees with Lohmeyer, Lightfoot and Marxsen with reference to the opposition between Galilee and Jerusalem in Mark, but also further darkens the prevailing negative view of Jerusalem found by these scholars.

According to Kelber (1974:137), Galilee (including the Decapolis and the area of Tyre and Sidon as outlined by Mark) is the setting in life (i e Sitz im Leben) for Mark. The major reason why the Gospel was written was the hope of the parousia. Kelber, however, differs from Marxsen in the sense by situating the Gospel in the aftermath of the Jewish war and the destruction of the temple. He argues furthermore that the Gospel was written as a polemical work of the north (Galilee) aimed at the ruined tradition of the south (Jerusalem) formed on Peter and the Twelve. According to his reconstruction, the religious leaders in Jerusalem, after Jesus' resurrection, betrayed Jesus' original vision. Self-styled Christian prophets of Jerusalem fell into an eschatological heresy that the parousia will occur in Jerusalem, and the family and the failed disciples of the Markan Jesus joined the Jerusalem authorities in opposing him. A conflict between Galilean Christianity and Jerusalem Christianity therefore exists in the Gospel.

For Mark, the place of the parousia and the kingdom is not Jerusalem but Galilee. The time of the occurrence of the parousia is not in Jesus' generation, but Mark's own time. Mark's writing therefore, tries to explain the extinction of the Jerusalem church and the abolition of Jewish legalism to vindicate the Gentile mission and emphasize the way of the cross. Although Kelber admits that Galilee has more than mere geographic meaning for Mark, with rather strong theological and symbolic overtones, he is of the opinion that, historically speaking, the emphasis on Galilee in Mark must also be understood from the fact that Jesus' actual ministry was aimed at the poor and oppres- 
sed in the despised northern province of Israel (see also Kealy 1982:216; Matera 1987a:12-14 for a more detailed summary of Kelber's position in this regard).

In a certain sense, therefore, Kelber's understanding of the opposition between Galilee and Jerusalem clearly stands in line with the work of Lohmeyer, Lightfoot and Marxsen. It can, however, also be said that, to a certain extent, Kelber challenges these earlier scholars' emphasis of Mark 14:28 and 16:7 and stresses the importance of Mark 1:14-15 and Mark 13 (Kelber 1974:3-15, 110). According to Kelber (1974:143), Mark 13 must ie understood as Mark's detachment from Jerusalem, and Mark 1:14-15 (the program of the Gospel) as Mark's attachment to Galilee. It must also be noted that Kelber (1974:129) moves the study of geographical settings in the Gospel in several new directions in that he sees the Galilee - Jenusalem polarity as only one of the important aspects of the spatial framework of the Gospel. Jesus' voyages on the sea, as well as his journeys on the way, are also important to him.

\subsubsection{Summary}

The historical-critical investigations into the opposition of Galilee and Jerusalem in Mark, as discussed in sections 2.2.1.1 to 2.2.1.4, yielded the result that a theological, eschatological and geographical opposition, historically and socially speaking, may have existed between the centers of Galilee and Jerusalem in the time of Mark's composition of his Gospel. According to Lohmeyer, the main reason for this opposition was a difference in the two centers' understanding of the cult and eschatology, thus a theological opposition: Galilee is the place gospel, the new 'kommende Gotteshaus', and Jerusalem that of the cult, the place of the traditional 'Gottestadt'. Lightfoot agrees with Lohmeyer in the sense that he also formulates this opposition in terms of eschatology. Because Galilee will be the sphere of divine revelation (the seat of the gospel), Jerusalem must be seen as the center of human rejection, the center of relentless hostility and $\sin ^{3}$. In this sense the opposition between Galilee and Jerusalem therefore also can be seen as geographical, implicitly derived from the theological opposition in the Gospel. According to Marxsen, at the time of the composition of the Gospel, the eschatological expectations in Galilee were so strong that Mark, by ways of his redactional activity, made Galilee the 'home' (present and future) of Jesus. For him, the opposition between these two centers is therefore both theological and geographical. For Kelber this opposition also was one of different understandings of eschatology, although he lays his emphasis in his study of the Gospel on the differences between the theological leaders of both centers in the aftermath of the destruction of the temple. 
It is, however, clear that historical concerns about the composition of Mark seem to have motivated the approaches of Lohmeyer, Lightfoot, Marxsen and Kelber. From these historical concerns, theological conclusions were drawn. In a sense, theology thus becomes eschatology, in that eschatology is taken as the key for understanding the opposition between Galilee and Jerusalem in the Gospel. From historical presuppositions theological conclusions thus emerged.

Regarding the above historical method that was used, it can be asked if the mode how exegetes relate internal evidence (the text itself) to external evidence (historicai occurrences, sociological reconstructions) is legitimate and if it can be helpful to understand the political dynamics of the text properly. My opinion is that it is and can be.

However, two important methodological questions will have to be answered first in regard to the way in which the above historical-critical scholars relate internal evidence to external evidence in their respective studies of the opposition between Galilee and Jerusalem in the Gospel of Mark. The first question is a question of form. Should Mark's gospel be studied as a historical document, or should it rather be considered as a historical narrative and therefore studied as such? If it is seen as a narrated historical record, the second question concerns the historical world and historical occurrences that are referred to in the narrative of Mark. Will a socio-historical analysis of the historical world of the text be legitimate, or should an interpretation be considered which employs (a) well-defined social-scientific model(s) 4 ? In section 2.5 it will be contested that these two questions indeed show the research gaps that exist in the works of Lohmeyer, Lightfoot, Marxsen and Kelber. Not only did they not take the literary form of the Gospel of Mark seriously, but their analysis of the first-century Mediterranean world of Galilee and Jerusalem lacks that of a well-defined social-scientific analysis. With such an analysis it may be possible to indicate if the identified opposition between Galilee and Jerusalem in Mark has to be understood only as a historical, geographical or theological opposition, or also as an ideological, or even a political opposition.

\subsection{GALILEE VERSUS JERUSALEM AS 'THE WAY' OF JESUS: A LTTE- RARY-CRITICAL ANALYSIS}

\subsubsection{Introductory remarks}

As has been noted in section 1.1, the insights of Lohmeyer, Lightfoot, Marxsen and Kelber concerning the opposition between Galilee and Jerusalem in Mark, served as stimuli for the literary-theoretical study of the structure of space in the Gospel of Mark. The main contributions of these scholars, as will be shown in sections 2.3.2 to 2.3.6, are twofold: First, the text of Mark as a literary unit is taken more seriously. Second, as a result of taking the text more seriously, these scholars brought a new and impor- 
tant aspect of the structure of space in Mark to the fore: The central aspect of Mark's spatial structure is that of 'the way' of Jesus from Galilee to Jerusalem. Understood as such, the opposition between Galilee and Jerusalem in Mark serves to highlight that 'the way' of Jesus (from Galilee to Jerusalem) can be seen as the central aspect of Mark's spatial structure.

\subsubsection{B M F van Iersel}

According to Van Iersel (1982a:117), the study of space in Mark from Lohmeyer up to Kelber had two points of departure in common which can also be seen as the research gaps in their respective works: First, their hypotheses are based on a questionable reconstructed history of a possible early congregation in Galilee, and second, the opposition between Galilee and Jerusalem was seen as the only spatial opposition in the Gospel. Because of these two research gaps, Van Iersel formulates his point of departure in studying space in the Gospel of Mark as follows: 'My contribution aims to study the more important units of space in Mark as an interdependent topographical system that function as to bring the meaning of the text to the fore' (Van Iersel 1982a:119; my translation and emphasis).

It is thus clear that Van Iersel's interest in the text lies in his aim to study all possible topographical relations that may be present in Mark. When all the spatial relations in Mark are taken into consideration, Van Iersel contends that the following topographical structure can be deduced from Mark's presentation of space in his Gospel (see Van lersel 1982a:136; 1983:42; 1989:18-305):

\begin{tabular}{|c|c|}
\hline the desert & (Mk 1:1-1:13) \\
\hline Galilee & (Mk 1:14-8:26) \\
\hline the way & $(\mathrm{Mk} 8: 27-10: 52)$ \\
\hline Jerusalem & (Mk 11:1-15:45) \\
\hline e tomb & (Mk 15:46-16:8) \\
\hline
\end{tabular}

In explaining this structure, Van Iersel $(1983: 48)$ holds the view that it functions in two ways in the Gospel; On the syntagmatic level (surface structure) of the text, space is presented by way of five linear sequences, that of the desert, Galilee, the way, Jerusalem and the tomb. On the paradigmatic level (deep structure) of the text, which is aimed at the reader, the first and the last sequences (the desert and the tomb) must be seen in unison and the second and fourth sequences (Galilee and Jerusalem) as in opposition to each other. Galilee and Jerusalem and the desert and the tomb are therefore concentrically organized in relation to the middle, and most importantly topographical sequence in the Gospel, the way. 
The opposition between Galilee and Jerusalem is expressed in the Gospel by the opposition between inter alia center versus periphery, rural areas versus urban areas, abundant fruit versus no fruit, many synagogues against one temple, beginning versus end, healing against no healing, and Jesus' authority against no authority. The unison between the desert and the grave on its turn is expressed by the eschatological messengers in Mark 1:7-10 and 16:6 and Jesus' statements concerning the way in Mark 1:1-2 and 16:7 (see also Van Iersel 1982a:126; 1982b:369-370),

According to Van Iersel (1983:45-52) this structure of space in the Gospel can be summarized, in relation to the work of Jesus, as follows: Central in the Gospel of Mark is the way on which Jesus must go. The sequences of the desert and the tomb describe this way as a way in which death and life play an important role. This way from life to death and to life again will be a way of conflict, which is expressed by the opposition between Galilee and Jerusalem. Jesus' way is therefore a way of suffering.

Van Iersel's' contribution is thus in a sense a complement on the work of Lohmeyer up to Kelber. For Van Iersel the most important topographical space in Mark is the way, and not Galilee and Jerusalem as in the contributions of Lohmeyer, Lightfoot, Marxsen and Kelber. The opposition of Galilee versus Jerusalem functions for Van Iersel only as an extension of 'the way' of Jesus in the Gospel, and not as the most important topographical aspect of the text.

\section{2,3.3 D Rhoads and D Michie}

The work of Rhoads \& Michie, Mark as story: An introduction to the narrative of a gospel (1982), was the first publication on Mark that took the narrative aspect of the Gospel of Mark as a whole seriously. By using Seymour Chatman's insights on the structure of a narrative (see Chatman 1978:9-43), Rhoads \& Michie note that every narrative can be viewed from two vantage points: The story, that is what the narrative is about (consisting of the events, time, characters and settings in the narrative), and the discourse, that is how the story is told (Rhoads \& Michie 1982:35-62; see also Chatman 1978:17-41),

In connection with the how of the story, namely it's rhetoric, the single most rhetorical device is that of the omniscient narrator, a narrator who knows the thoughts and feelings of all the characters in the story and which is not bound by time and space. This narrator furthermore represents an ideological point of view 6 , that is a system of values, by which he interprets the story for the reader. In Mark the point of view of the narrator is aligned with that of Jesus (Rhoads \& Michie 1982:35-42).

When Rhoads \& Michie tums to the what of Mark's Gospel, they maintain that the different settings in the Gospel (e $\mathrm{g}$ the sea, mountain, river, desert) are responsible for the overall movement and development of the plot of the Gospel. However, the central setting in the story, which is also a product of the narrator's point of view, is the move- 
ments of Jesus through Galilee and his journey to Jerusalem and the temple. This journey (as the way of Jesus) not only creates 'a funneling effect for the whole story' (Rhoads \& Michie 1982:70), but also functions as the background for the plot of Mark. This is worked out through a series of conflicts with inter alia the disciples and the religious authorities (Rhoads \& Michie 1982:63-72). The conflict with the religious leaders arises because they have ruled for themselves rather than for God (cf Mk 12:1-12). This conflict is finally resolved when the religious leaders obtain their wish to put Jesus to death (for a more detailed summary of Rhoads \& Michie's viewpoint see also Rhoads 1982:411-434; Van Eck 1984:28-32; 1988:149-150; Matera 1987a:88-92).

\subsubsection{N R Petersen}

Petersen was one of the first scholars who applied literary criticism to Mark's gospel (see Petersen 1978:49-80). As a literary critic, Petersen sees the text as a whole, a world which, once created by the implied author, takes on an existence of its own. Although Petersen's interest in reading Mark was not directed towards an analysis of space in the Gospel, the results of his study concerning the relation between Mark 13 and Mark 16:7-8 has some importance for the understanding of the narrator's application of the focal spaces Galilee and Jerusalem in Mark (Petersen 1978a:112-118; 1980a:151-166).

According to Petersen's analysis of Mark the 'storyteller's principal plot device is one of prediction and fulfillment' (Petersen 1980a:155). By this he means that all the predictions in the Gospel are also fulfilled in the Gospel itself. This, however, seems not to be the case for the prediction in Mark 16:7. In trying to unravel this peculiarity in Mark, Petersen (1980a:157-162) takes two points of departure: First, it is impossible for this prediction not to be fulfilled in the text because it would assault the narrator's own credibility. Second, a solution for this problem may possibly lie in an ironic reading of the text that distinguishes between, on the one hand, the narrative world and narrative text of the narrator, and, on the other hand, between story time and plotted time in the Gospel (Petersen 1978b:49-80; 1980a:155-1617). Taking these distinctions in consideration, Petersen (1980a:158-160) comes to the conclusion that Mark 13 must be seen as the fulfillment of the prediction in Mark 16:7-8.

The importance of Petersen's understanding of these texts for our study of the opposition between Galilee and Jerusalem as settings in Mark is the following: Jensalem is not only 'conquered' by Galilee in the Gospel itself, but also in the 'open end' of the Gospel (see Petersen 1980a:157).

In a sense, therefore, the results of Van Iersel and Rhoads \& Michie concerning the relation between Galilee (as the 'domain' of the successful Jesus) and Jerusalem (as the 'domain' of the opposition to and killing of Jesus) is complemented by the results of 
Petersen. Because, for Petersen (1980a:161-162), the setting of Mark 13 is that of Galilee, the end of Mark is not its end, but in fact its beginning. As the Gospel started in Galilee, so it ends in Galilee. But it also begins in Galilee again. For Petersen, therefore, there is not only an explicit opposition between Galilee and Jerusalem in the Gospel itself, but also in the open-end of the Gospel. Because the Gospel starts and ends in Galilee, the opposition between Galilee and Jerusalem is made much more explicit. (For a more detailed summary of Petersen' point of view, see also Van Eck 1984:47-52; 1988:154-156; Vorster 1987b:203-2248; Dewey 1989:32-44.)

\subsubsection{E S Malbon}

Malbon's work on the meaning and structure of space in Mark can, without contradiction, be called the most extensive of any scholar up to date (see Malbon 1979, 1982, $1984,1986 \mathrm{a}, 1986 \mathrm{~b}$ ). Her work on space in Mark can be called a structural analysis of the spatial/mythical relations in Mark based on the hermeneutical theory of Claude Lévi-Strauss, which she adapted slightly (see Malbon 1986a:2-8). What Malbon is most interested in is an exposition of the mythical structure of Mark as mediated through the spatial relations in the narrative. Malbon, therefore, is trying to uncover the 'deep structure' of Mark as it is manifested in the various spatial relations in the Gospel. This she does by considering all Markan spatial locations in their system of relationships and to consider the significance of this system in terms of an 'underlying, nonmanifest, mythological system' (Malbon 1986a:2). Although Mark is not myth, it does contain a mythical structure (Malbon 1986a:3).

Following Lévi-Strauss, Malbon notes that myth operates to mediate irreconcilable oppositions by successively replacing them with oppositions that permit mediation. The basic opposition in any text is that of the syntagmatic and paradigmatic aspects of the text. The syntagmatic constraint constitutes the sequential ordering of the text, and the paradigmatic aspect constitutes the relational patterning of the text ${ }^{9}$. Applied to space in the Gospel, the syntagmatic aspect of the text is the chronological ordering of the different settings to which the narrator refers, and the paradigmatic aspect is the different relationships that exist between the settings which occur in the chronological narrating activity of the text's narrator.

In applying the above mentioned model, Malbon divides the spatial order of Mark into three suborders: the geopolitical, topographical and architectural. The geopolitical schema consists of the opposition familiar and strange, which is replaced by Jewish homeland and foreign lands, then by Galilee and Judea, and finally by the environments of Jerusalem and Jerusalem proper (see Malbon 1986a:40). The major shift in the geopolitical suborder occurs in Mark 10:1, where the story about Jesus shifts from Galilee to Jerusalem, that is from a ministry of power to a ministry of suffering (Mal- 
bon 1986a:30-31). The topographical suborder, on its turn, consists of the opposition between promise and threat, which is replaced by the triad heaven, mountain and earth (the mountain is the mediating space between heaven and earth), heaven and earth on its turn is replaced by land and sea, which is replaced by isolated areas and inhabited areas and finally is replaced by the way (see Malbon 1984:363-377; 1986a:97). While the geopolitical suborder suggests a surprising reversal of expectations in Mark concerning the work of Jesus, the topographical suggests how such a reversal is possible, that is by following on the way (Malbon 1986a:150). Finally the architectural suborder is that of profane versus sacred, which is respectively replaced by house and synagogue/temple, then by room and courtyard and finally by tomb and temple. In the architectural suborder, therefore, a reversal of expectations again occurs when the tomb fails to become the final place of Jesus' dwelling.

From this summary of Malbon's point of view on space in Mark, it is clear that she sees the function of each of these three spatial suborders as subverting the expectations of the reader, thereby reflecting the parabolic nature of the Gospel (see also Cross 1975:59 for the same understanding of the function of parable and myth ${ }^{10}$ ). The binary oppositions which make up the spatial schema of Mark, for Malbon (1986a: 168), therefore are mediated in the narrative in the topographical suborder 'the way', Thus, the fundamental mythical opposition between order and chaos is overcome 'not in arriving, but in being on the way' (Malbon 1986a:168; see also Harris 1988:61-70 for a more detailed summary of Malbon' understanding of space in Mark).

\subsubsection{J D Kingsbury}

Although Kingsbury (1989), in his narratological analysis of Mark, does not refer explicitly to the opposition between Galilee and Jerusalem in Mark, his reading of Mark is included here for two reasons: First, his reading of Mark is an example of a consequent narratological analysis of Mark, and second, because the title of his book, Conflict in Mark, suggests some (political) conflict in the Gospe] ${ }^{11}$. In short, Kingsbury (1989:3-5) argues that the main goal of Mark is to narrate the story of Jesus. In the storyline of Jesus' identity and destiny are interrelated. Not until Jesus' destiny of death on the cross has been narrated does any human being other than Jesus himself or the reader perceive the mystery of his own identity.

Intertwined with the story of Jesus are two other story lines in the Gospel, that of the religious authorities, and that of the disciples. The story of the religious authorities is that they act as those 'without authority' (Kingsbury 1989:87). On the other hand, the story of the disciples is that of followers of Jesus who are at once loyal to him yet uncomprehending. 
The goal of Kingsbury's book is to trace and interpret the conflict between this three story lines. The shortcoming of Kingsbury's reading of Mark, however, is that he never tries to relate this identified conflict in Mark to the first-century Mediterranean social setting of the Gospel. This is also, in my opinion, the first research gap in his narratological reading of Mark. The second shortfall of his work is that he nowhere spells out the narratological theory/model that he is using, and therefore his results cannot be verified in terms of such a model 12 . The third and last research gap of his reading of Mark (although it is not his intention as such) is the fact that he nowhere attends to the possible meaning that the different spatial relations in the Gospel may have on an understanding of his identified conflict in the Gospel. These research gaps will be attended to in section 2.5 .

\subsubsection{Summary}

The historical-critical investigations into the opposition of Galilee and Jerusalem in Mark as discussed in section 2.2 yielded the result that a theological, eschatological and geographical opposition, historically and socially speaking, may have existed between the centers Galilee and Jerusalem in the time of Mark's composition of his Gospel. As has been noted in sections 1.1 and 2.3.1, the insights of Lohmeyer, Lightfoot, Marxsen and Kelber, in regard to the opposition between Galilee and Jerusalem in Mark, served as stimuli for the literary-critical studies of the structure of space in the Gospel of Mark as described in sections 2.3.2 to 2.4.6 ${ }^{13}$. By using the insights of Lohmeyer, Lightfoot, Marxsen and Kelber as a starting point, and by taking the literary structure of the text seriously, new results were brought to the fore.

According to Van Iersel (1982a, 1982b, 1983, 1989), Galilee and Jerusalem indeed are opposed in Mark, but this opposition is not the only one that can be deduced from the text: In Mark there are two main oppositions, the desert versus the tomb and Galilee versus Jerusalem (in terms of inter alia periphery versus center and rural versus urban areas). These two binary oppositions, however, serve to highlight the main spatial reference of the-Gospel, namely 'the way' of Jesus. This way is a way from the desert to the tomb (in which life and death play an important role), and from Galilee to Jerusalem (a way of conflict between Jesus' activity in Galilee and the Jenusalem religious leaders' evaluation thereof). Understood as such, Jesus' way is a 'way of suffering'. For Rhoads \& Michie this is also the case, in that they see the activity of Jesus as a conflict between 'ruling for God' and the religious leaders that 'rule for themselves' (cf especially Mk 8:33; 12:1-12).

Also Malbon sees Jesus' activity as resolving this opposition by 'not arriving, but being on the way' (Malbon 1986a:168). According to Malbon (1986a:40), three spatial suborders can be indicated in Mark's gospel: The geopolitical, the topographical 
and the architectural. The geopolitical suborder consists inter alia of the opposition between familiar/Jewish homeland and strange/foreign lands; the topographical suborder relates inter alia to the way of Jesus from Galilee to Jerusalem; and the architectural suborder inter alia relates to the opposition between house and temple. By being on the way, Jesus resolves all these spatial oppositions in the Gospel, but by doing it, his way becomes a way of suffering. This also is the conclusion of Petersen: The Gospel not only starts in Galilee, but also ends in Galilee (Petersen 1980a:151-166). Jesus' way is a way from Galilee, through suffering in Jerusalem and back to Galilee. As Jesus suffered by being killed for his 'way' in the Gospel, so will the disciples suffer in the future by walking on the same 'way' ( $\mathrm{cf}$ Mk 13:9-13)14.

For these scholars, therefore, the opposition between Galilee and Jerusalem is not the most important spatial issue in Mark, but rather the way/activity of Jesus' suffering. Understood as such, the opposition between Galilee and Jerusalem in Mark serves to highlight 'the way' of suffering of Jesus (as a way from Galilee to Jerusalem). The 'way' can therefore be seen as the central aspect of Mark's spatial structure.

A definite shift in the understanding of the opposition between Galilee and Jerusalem in Mark can therefore be indicated in terms of the results of, on the one hand, the historical-critical scholars discussed in sections 2.2.1.1 to 2.2.1.4, and, on the other hand, the literary-critical scholars discussed in sections 2.3.2 to 2.3.6. Where the historical-critical scholars understand and try to explain the opposition between Galilee and Jerusalem in terms of historical, : ${ }^{+}$ological and eschatological differences in the early church, this opposition is seen by the above mentioned literary critics as a result of Jesus' way of suffering from Galilee to Jerusalem. Because Jesus' activity in Galilee is questioned by the religious leaders in Jerusalem, conflict arises, and therefore Jesus' proclamation of the arrived kingdom of God becomes a way of suffering.

In sections 1.1 and 2.3.1 it was indicated that a literary-critical approach has the advantage that the text is taken more seriously as literary whole (cf e g Petersen 1978:49-80; Rhoads \& Michie 1982:35-65; Van Iersel 1982a:119; Kingsbury 1989:35). From the above discussion it became clear that, in regard to the study of space in the Gospel of Mark, this approach enabled the mentioned literary-critical scholars to build on the insights and results that were yielded by the historical-critical approach: Central in Mark's spatial structure is the way of Jesus, a way of suffering which starts in Galilee and ends in Jerusalem. However, as will be indicated in section 2.5, literary-criticism, by concentrating on the text only, has a shortcoming: It does not take the first-century Mediterranean world in which Mark as text evolved into consideration.

To such studies of the Gospel of Mark we now turn our attention in section 2.4. In this section, it will be indicated that Belo (1981), Myers (1988) and Waetjen (1989) analyze Mark's story of Jesus in terms of their respective understandings of the socio- 
economic background of first-century Mediterranean society (as a stratified agrarian society). This enables them to understand Jesus' way as a way of suffering, that is, as a result of the fact that the narrator of Mark depicts the opposition Galilee and Jerusalem as a political one.

\subsection{JESUS' WAY OF SUFFERING IN MARK: A POLITICAL OPPOSITION BETWEEN GALILEE AND JERUSALEM}

\subsubsection{Introduction}

In section 2.3.7, it was concluded that the study of space in Mark underwent a shift of emphasis: While the discussed historical-critics elucidated the opposition between Galilee and Jerusalem in terms of historical differences between the two centers in the early church, the literary-critics explained this conflict/opposition in terms of the activity of Jesus in the Gospel as described by the narrator.

In the three ideological-critical readings of Mark, which are discussed below, this activity of Jesus is studied in terms of the social setting of the Gospel. According to Belo, Jesus was committed to subvert Palestine's economic system. Myers sees Mark's story of Jesus as a 'war of myths' between Jesus and the ruling elite (Pharisees, scribes, chief priests and elders). According to Waetjen, the Gospel of Mark tells the story of Jesus, which mainly consists of the construction of 'the way' from Galilee to Jerusalem. On this way, Jesus reorders power in and on behalf of the new community of God, and because of this, is opposed by the ruling elite.

However, although Belo, Myers and Waetjen's respective points of departure in reading the Gospel differs, they all conclude that the opposition between Galilee and Jerusalem in Mark can be seen as a political opposition. We now turn to a discussion of their respective works.

\subsubsection{F Belo}

Belo's (1981:xi) materialistic reading of the Gospel of Mark 'is the fruit of passion and naiveté', with the purpose 'to make possible a confrontation between a political practice that aims to be revolutionary, and a Christian practice that no longer aims at being religious' (Belo 1981:1). Because most modern (bourgeois) biblical scholars operate from the concept of faith, and not practice, Belo (1981:2) feels that nowadays an epistemological crisis can be denoted in theology ${ }^{15}$. This epistemological crisis is the result of class struggles which are part and parcel of the modern Christian world, and by just addressing faith when biblical texts are analyzed, modern biblical scholars are missing the need of today's Christian communities. 
To fill this need, Belo $(1981: 3)$ is of the opinion that a reading of the biblical text from a materialistic viewpoint must be seriously considered. Belo (1981:2) also feels that, because Mark is structured as a narrative of practice ${ }^{16}$, it lends itself perfectly to a materialistic reading. In his materialistic reading of Mark, Belo uses Barthes' method of 'structural and textual analysis'17 (see Belo 1981:89-97), employs Althusser's theory on the distinction between historical and dialectical materialism ${ }^{18}$, and as point of departure, takes Balibar's reference to the absolute invariance in the elements which are found in every social structure: an economic base with political and ideological forms'19 (Belo 1981:4). In regard to the latter, Belo (1981:7) therefore argues that the economic instance can be seen as the dominant structure in society.

Belo's work is divided into four parts (contra Domeris 1991a:30620). The first part of the book (Belo 1981:7-33) is an essay in formal theory which deals with the Marxist concept of the mode of production and consumption. According to Rice (1982:71) '[t]hese hypotheses, although claimed by Belo to be original with him, are rooted in Marxist philosophy'. A simplifying of Belo's understanding of the concept 'mode of production' amounts to two important aspects in society: The relationships of production between producers and non-producers, and the forces of production. Seen from these two aspects, Belo concludes that the mode of production is the base ( $\mathrm{i}$ dominant) of any particular society.

Because Belo sees the economic instance as the dominant institution in any society, he turns in the second part of his book to the mode of production in biblical Palestine to expose the socio-economic setting of the biblical writings in order to show the relevance of such concepts as mode of production and class struggle (Belo (1981:37-86). In this regard, Belo is of the opinion that in ancient Palestine, the law defined the symbolic universe and symbolic order that regulated the relationships between persons in the social formations of table, house and sanctuary: 'The Law constitutes ... the symbolic order that regulates the relations between the bodies of the agents of the social formation, which is the Law's symbolic field' (Belo 1981:37). In connection to the law as symbolic order, Belo (in following Von Rad 1965, Gottwald 1979, Brueggemann 1983) discerns within the Old Testament legislative texts two opposing systems: The Yahwist system based on gift (the debt-system) and concerned with equality and tribal self-rule which was favored by the common people of the land. On the other hand there was a system favored by the ruling classes which was based on the concepts of pollution versus purity which was priestly, oppressing, centralizing and bureaucratic in its focus on the exercise of sacral and royal power (see also Fuessel 1983:135). According to Belo (1981:56-58), the priestly case laid emphasis on the pollution system to attain a privileged position in society. They further consolidated their position by 
using the debt system, which was preferred by the lower classes, in terms of tithes to the temple to get even more political and economic power. According to Belo (1981: 38 ), beginning at a certain period in the subasiatic monarchy, these two systems were related to each other by a dialectic which is that of class struggle. This dialectical relationship between these two systems also gave the temple its political and economical centrality. It was because of this situation that the rebellious group, called the Zealots, arose as one of the manifestations of the political instances of biblical Palestine.

It is then from this identified symbolic order, class struggle and emphasis on the temple that Belo (1981:99-240) sets out to read Mark, and especially the activity of Jesus. In reading Mark, Belo (1981:98-232) divides the text into seven sections. In the first section (Mk 1:1-15) we find a circuit of voices (i e that of God [heaven], Jesus and John) which program the text to follow in terms of a topographical code: The itinerary of Jesus from Galilee to Judea (temptation) and back to Galilee anticipates Jesus' later itinerary in the Gospel, that is from Galilee to Jerusalem (Judea) to temptation and death and back to Galilee. Jesus' descent from Galilee here also anticipates his later ascent to Jerusalem. In the first fifteen verses we thus find a programmatic loop with it's own opening and closure, and therefore, also the determination and boundaries of Jesus' activity.

The second section is comprised of Mark 1:16-3:6. This section is characterized by a narrative of three types of practice on Jesus' part, namely new teaching, expulsion of demons and healing. This practice gives rise to the strategy of the crowd to seek out Jesus wherever he is, and also Jesus' strategy to avoid the crowd as much as possible. In this section (especially Mk 2:1-3:6), Jesus also sets out to subvert the Jewish symbolic social world in terms of their understanding of the pollution- and debt systems. Jesus' interpretation of these two systems is 'to save a life', while that of the Pharisees is 'to take a life' ( $\mathrm{cf}$ Mk 3:1-5). These two antithetical strategies also define the goals of Jesus and the Pharisees later in the Gospel, as will be seen in Mark 8:31-13:36, the sixth section in Mark that Belo identifies which revolves around Jesus' cleansing ('replacing') of the temple. The references to the Son of Man in section three, which deal with the sabbath and sinners, as well as the metaphor of the bridegroom, also refer to the eschatological kingdom of God that Jesus represents.

The main object of section three (Mk 3:7-4:34) is Jesus' use of parables to set off the disciples from the crowd. In this section, it is clear that Jesus' dominant strategic concern is to teach his disciples the correct reading of his practice (cf Mk 4:35-5:1; $7: 1-24 ; 8: 13-22)$. This practice of Jesus is threefold: First, it is a practice of power in relation to the bodies of those that have been afflicted with uncleanness. Second, it is a practice of teaching (that is to read Jesus' practice of power correctly), and finally, it is a practice of subverting the Jewish symbolic field and symbolic order in terms of his 
own understanding of the systems of pollution and debt. This threefoldness of Jesus' activity enables Jesus' practice to relate to three sites of the body of his followers; First, the hands that touch, second, the eyes that read and ears that hear, and finally, the feet that move about.

The fourth section (Mk 4:35-8:30), called the sequence of the boat, can be divided into two sub-sequences, that of the twelve (Mk 4:35-6:13) and that of the loaves (Mk $6: 14-8: 30)^{21}$. The sequence of the twelve tells of the completion of Jesus' mission in Galilee and the part played by the disciples in this mission. The goal of the sequence of the loaves is twofold: First, in feeding the crowds, Jesus widens the horizon of his practice to embrace also that which lies beyond the borders of Israel, the pagans. Second, Jesus' constant efforts to separate the disciples from the crowd must be seen as an effort from his side to lead the disciples to read his practice as messianic, and the crowd to read it as zealotic. However, Peter's response in Mark 8:29 shows that the disciples see Jesus, despite all his efforts to show them otherwise, as a leader of the zealot type ${ }^{22}$.

Because of this, the fifth section (Mk 8:31-13:36), according to Belo (1981: 155204), is structured around Jesus' destruction of the temple and the recognition/failurein-recognition of the disciples relating to the true messiahship of Jesus. Jesus' destruction of the temple can be seen as a final consequence of his practice of subverting the Jewish symbolic field (of which the temple is the main center), but also because of the rejection of his messiahship by the chief priests, scribes and elders. A further consequence of Jesus' cleansing of the temple is that it announces a shift from the mission of Jesus to Israel to a mission to the pagans. Finally, the destiny of the temple was also at stake in connection to the opposition between the strategy of Jesus and that of the Zealots. Where the Zealots focused on liberating the temple and Israel from the Roman occupiers, Jesus' strategy was to abandon the temple and to opt for a new exodus to the pagans. The teaching of Jesus by using the scheme of 'the road', and his call 'to be followed after' can also be seen as relating to this exodus. This opens up the possibility for the new ecclesia without the presence of Jesus.

The oppositions child/adult, servant/master, first/last and rich/poor define the boundaries of this new community. Furthermore, the opposition between Jesus and the temple shows that in this new community, the economy of the temple-treasury ${ }^{23}$ will be replaced by Jesus, a gift which should be for the benefit of all. The life in the new community will be that of the question between 'losing one's life' (if the community falls back into the symbolic system of the religious leaders) and 'gaining one's life' (by living according to the new rules of Jesus). This, however, will only come accompanied by inevitable persecutions on the part of the classes that have authority, namely the scribes, chief priests and elders. 
In the penultimate section of Mark (Mk 14:1-14:72), the two opposing strategies of Jesus and his adversaries become even more distinct. Jesus is extending his mission to the pagans while his adversaries are trying to kill him because of the new mission. Here the way Judas acted is an example of how one should not live in Jesus' new community, and the way Peter acted (by repenting) is an example of how one should live in the new community of Jesus.

In the last section (Mk 15:1-16:8), it becomes clear that Jesus' scathing attack on the temple inevitably led to his trial and death. Because the temple was the seat of economic power of the ruling elite in Judea, and Jesus attacked their economic power by abolishing the temple, they had no other choice than to kill Jesus. For Belo the trial of Jesus therefore centers on two rival ideologies: The prevailing ideology of the ruling elite that grows out of the temple's mode of production, and Jesus' ideological commitment to replace the temple, which arises out of his practice of the hands, ears and eyes, and feet.

In part four of his book Belo (1981:241-297), translates his above mentioned conclusion, namely that Jesus ministry to the poor in his time was a ministry of the hands, feet and eyes, into a materialistic ecclesiology, that is in terms of the 'struggle' of today's poor and believers. Jesus' ministry of the hands, which transforms bodies, consists of a practice that is operative on the economical level ${ }^{24}$. The Pharisees' objection that healing is a work forbidden on the sabbath, the narratives of the loaves where Jesus replaces buying with giving, the rich man that must go and sell everything and give to the poor and the temple-economy that is replaced by Jesus with a ecclesial economy correlates to this practice of the hands. Materialistic ecclesiology at the economic level therefore consists in the extension to the whole world as a table where all the poor are fed and filled. To love the poor person as yourself amounts to seeing to it that he or she is filled as you are. This practice of economic love is called charity.

The practice of the feet is the movement of Jesus from place to place, the geographical extension of Jesus' practice to all, especially the outsiders and the poor. This leads to a new family, not based on blood or master-servant relations, but on equality. One becomes part of this new ecclesia by way of conversion, that is a break with society as understood by the religious leaders (i e, in terms of the law) and the codes that regulate it. This puts this practice of Jesus in the sphere of the political. Jesus' opposition to the hierarchy of classes in early Palestine, his subversion of the social (temple) structure as political instance, his mission to the pagans and his founding of a new community in Mark, correlates with this. This new community of Jesus without any classes is called a community of hope. Finally, the practice of the eyes is 
to see what is right and wrong in any system of classes, and also to dismantle the ideology that governs any such society. It is therefore messianic practice on the ideological level and is to be called a practice of obedience in faith.

This strategy of Jesus' messianic practice, therefore, has all the markings of a radically communist strategy (Belo 1981:261). It is however, a non-revolutionary strategy (Belo 1981:261), in that it does not aim to eliminate class systems in current societies, but rather aims for a communist ecclesiality: A gathering of a circle of poor people without any rich people, servants without any masters, that is, sons of man without any relations of domination or kinship. This was also the new community Jesus created among the pagans.

To summarize: Belo's aim is to read Mark with the help of Karl Marx. According to Belo, Jesus was committed to subvert Palestine's economic system. So were the Zealots, but they aimed at restoring the pre-Roman subasiatic economy, while Jesus wanted to institute communism. The chief obstacle to Jesus' communist program was temple-centered Palestine. Its pollution-code governing food, sacrifice and sex supported the interests of the dominant class. Deuteronomy and the prophets had tried adding to it some concern over what human beings owed each other. Their failure convinced Jesus that the whole temple-system had to be abandoned in favor of an ecclesia among the pagans.

Jesus begins his subversion of Palestine's economic system by healing, teaching and expelling demons. By this, he subverts the scribes and Pharisees' understanding of the pollution system. When Jesus feeds the multitudes with only five loaves, he acts out his messianic message: Give all you have to fill the hungry, and there will be plenty for all. Eventually it seems that Peter understands who Jesus is, by proclaiming him as the Messiah. However, because it is clear to Jesus that Peter still does not understand what he wants to do, Jesus goes on to destruct the temple. Jesus realized that if he could draw the authorities' hatred to himself alone, his disciples might have more of a chance to survive and take his cause to the world.

Later the disciples added a theological dimension to Jesus' story: Jesus' fate had been planned by God and was a sign of a definite, divine righting of wrongs (Belo 1981:237-238). When the Zealots' rebellion failed in $70 \mathrm{CE}$, Mark wrote his gospel to remind the Christians of Rome that now all would be fulfilled, and that the churches should fulfill their task by sharing with the poor. This task is ours today, though bourgeois exegetes remain blind to it and try to spiritualize the gospel. This task demands promoting the communist future by supporting all present-day revolutions against capitalism, even with the violent means which did not fit Jesus' historical situation (Belo 1981;267-297). 
Belo thus views Mark as a subversive text, not because it contains radical ideas but because it narrates a subversive practice, the messianic behavior of Jesus and the community he sought to build. Its subversive character resides not only in the new teaching of Jesus but in the new family he founded and in his own willingness to confront the Jewish establishment of his day (for other summaries of Belo's reading of Mark see Quesnell 1982:130-131; Rice 1982:70-72; Westphal 1982:37-38; Davies 1983;63-64; Krentz 1983:58-59; Scroggs 1983:473-474).

\subsubsection{Myers}

As the starting point for his political reading of Mark, Myers (1988:9) contends that nowadays a 'battle for the Bible' exists in theological hermeneutics. This battle is fought between, on the one hand, bourgeois exegetes that practice a hermeneutics of privatism, see conversion as a fundamentally private affair and approach texts as neutral archaeologists. They therefore practice a theology that not only has nothing to say for 'the struggle for the rights of the oppressed in this world' (Myers 1988:73), but is also 'nothing less than a perpetuation of the docetic heresy' (Myers 1988:9). On the other hand, however, Myers (1988:9) contends that certain scholars see that this 'battle for the Bible' is less and less a theological issue and more and more an issue of politics and economics. Because, according to Myers (1988:73), 'the purpose of theology is political critique of the dominant, oppressive order at the level of its social-symbolic ordering of thought and historical process ${ }^{25}$ ', he wants to read Mark as 'an ideological narrative, the manifesto of an early Christian discipleship community in its war of myths with the dominant social order and its political adversaries 26' (Myers 1988:31). Myers thus intends that his commentary on Mark will contribute to a political theology that empowers people for political struggle.

In reading Mark, Myers makes use of the insights of Yoder's theory of political nonviolence 27 (Myers 1988:81-87, 460-461), Gottwald's socio-historical reconstruction of biblical Palestine in terms of class conflict ${ }^{28}$ (Myers 1988:47-55), Horsley \& Hanson's analysis of the socio-economic situation in biblical Palestine ${ }^{29}$ (Myers 1988:58-64), Douglas' understanding of the symbolic universe of early Palestine in terms of the concepts of purity and danger ${ }^{30}$ (Myers 1988:70-80) and finally, Chatman's prescriptions of what a narrative is and how it should be read ${ }^{31}$ (Myers 1988:3138). Myers' main theoretical intent is an attempt to combine an extrinsic reading of Mark, which examines 'the historical and ideological setting and prevailing social strategies of Mark's 'world' (Myers 1988:31), with an intrinsic reading, 'the inductive study of the text, employing ... literary analysis' (Myers 1988:31). Myers thus attempts to combine a social and literary reading of Mark, which is also one of the 
main points of intent of this study. By combining these two, Myers hopes to overcome disadvan-tages that accrue to each taken in isolation: The tendency of sociological criticism to repeat the fault of historical criticism in placing more value upon the preliterary traditions than upon the text itself (loss of narrative integrity), and the tendency of literary criticism to degenerate into 'aestheticism' or pure formalism (loss of historical integrity; see Myers 1988:31-38).

Myers (1988:40-42) further opts for a rural, small village environment in Galilee as the social location for the origin of Mark's Gospel, in which the peasants, as followers of Jesus, stood against aggregate urban power, especially the Jerusalem aristocracy. According to him, the Gospel was written during the Jewish revolt, 66-70 $B C E$, prior to the fall of Jerusalem, when the Galilean peasants were being recruited to enlist in the Zealot revolt. Using Holzner's types of subversive social strategies in coping with oppressive powers (Myers 1988:85-87), he locates Jesus and his followers within the alienative/confrontative ${ }^{32}$. This means that Jesus and his followers, though alienated from the oppressive power system, were politically engaged and non-reformist in the sense that they, by 'appealing to the subversive system of the great prophetical social critics of Israel' (Myers 1988:85), undertook to 'unmask the oppressive economic self-interest of the Jerusalem hierarchy, their tithing structure, sabbath regulations, and temple' (Myers 1988:86). This, according to Myers (1988:86), 'delegitimized both the Roman presence and the authority of the Jewish aristocracy as it was embedded in the debt and purity systems and reinforced in the temple cult and the dominant interpretations of the Torah'.

Turning to the text of Mark, Myers (1988:109-121) sees Mark as a narrative consisting of two 'books', two narratives with the same content and structure that revolves around a 'narrative fulcrum', Mark 8:22-26 (Myers 1988:116). This structure, as identified by Myers, can be summarized as follows (see Myers 1988:112);

Narrative theme

Prologue/Call to discipleship

Campaign of direct action

Construction of a new order

Extended sermon

'Passion' tradition

Symbolic epilogue
Book I

1:1-20

1:21-3:35

4:35-8:10

4:1-34

6:14-29

8:11-21
Book II

8:27-9:13

11:1-13:3

8:22-26; 9:14-10:52

13:4-37

$14: 1-15: 38$

$15: 39-16: 8$

According to Myers (1988:112-115), each prologue introduces the essential characters and plot compilations of each book. Each takes place on the way, discusses the relationship between Jesus and John-as-Elijah, and articulates a call to discipleship. In 
each book, this is followed by a campaign of direct action which consists of a series of conflict stories which dramatize Jesus' challenge to the Jewish symbolic order as it determined the everyday social life of the peasants. Both campaigns also involve confrontative actions in terms of healings and exorcisms. These two campaign narratives are complemented by two sections that function mainly to legitimate the alternative social practice that Jesus is advocating. This in turn is respectively followed by an extended sermon of Jesus, which Myers (1988:113) calls 'a moment of literary reflection' ${ }^{33}$. This is followed by two passion narratives, that of John in Book I and Jesus in Book II. The general structural symmetry in Mark is finaliy completed by two respective symbolic epilogues, a call to both the disciples and the reader to 'reread' the narrative. Let us look into these different narratives in more detail.

\section{BOOK I}

\section{Prologue/Call to discipleship (Mk 1:1-20)}

According to Myers (1988:122-136), four aspects in the prologue of Book I are of importance: First, the word 'gospel' in Mark 1:1 would have been understood by Mark's first audience as 'a technical term for news of victory'. Because, in the Roman empire, this word was especially associated with political propaganda, Mark's use of this word can be seen as a direct challenge to the apparatus of imperial propagation. '[I] $t$ is a declaration of war upon the political culture of the empire' (Myers 1988:124). Second, by alluding to Malachi in Mark 1:2, one of the last true prophets (Horsley \& Hanson 1985:146), Mark is telling his audience that the long-awaited eschatological judgment has drawn nigh at last (Myers 1988:125). Third, according to Malachi 3:1, this judgment would have taken place in the temple, however, for Mark it will take place in the wilderness (Mark 1:3), a spatial designation in Mark that refers to the peripheries (thus referring also to the outcasts, the target of Jesus' mission) of society. Mark is thus creating a spatial tension between two opposite symbolic spaces: The temple and its representatives, and the periphery with its representatives, namely the oppressed and marginalized in the society. Or, stated differently in Myers' own words: '[T]he main geopolitical opposition in Mark is between the social periphery (positive) and the center (negative), which is of course itself a reversal of the dominant code'. Finally, during his baptism Jesus is declared as 'an outlaw' so to speak; he will be the one that will challenge the oppressive structures of law and order around him (Myers 1988:130).

\section{Campaign of direct action (Mk 1:21-3:35)}

From the moment Jesus enters a Capernaum synagogue, it becomes clear that Jesus' understanding of the kingdom is incompatible with the local public authorities and the social order they represent (Myers 1988:137). A 'demon' immediately dernands that 
Jesus justify his attack upon the authority of the scribal establishment (Mk 1:21-29). This demon, according to Myers (1988:143), can be seen as representative of the scribal establishment, whose authority undergirds the dominant Jewish order. By exorcising the dermon, Jesus begins his confrontation in the war of myths with the scribal authorities. Understood as such, Mark establishes 'the political character of exorcism as symbolic action' (Myers 1988:143). Jesus' main objective, therefore, is to bring wholeness and liberation to the poor. When Jesus declares the leper clean in Mark 1:40-45, he is sent to witness against the priests who are in control, and through this, he overturns the symbolic order of purity of which the man is a victim (Myers 1988:153). By healing the paralytic (Mk 2:1-12), Jesus' political struggle truly commences: He has come to wrestle away from the scribal and priestly class their 'authority on eartth' (Myers 1988:155). In Mark 2:16-28, Jesus challenges the Pharisaic privilege and power by abolishing their rules of table fellowship, public piety and maintenance of the sabbath (Myers 1988:158). The climax of Jesus' campaign of direct action comes when he, in Mark 3:20-30, as the stronger one' (cf Mk 1:8) overthrows the reign of the strong man (the scribes).

\section{Extended sermon (Mk 4:1-34)}

According to Myers (1988:169-181), Jesus' parables in Mark 4 can be seen as an 'ideology of the land' (Myers 1988:176). By telling his audience that the different seeds planted 'yielded thirty, sixty and hundredfold' (Mk 4:9) and become the 'greatest of all shrubs' (Mk 4:32), he is saying the kingdom is like this: It envisions the abolition of the oppressive relationships of production that determined the horizons of the Palestinian farmer's social world. 'Such images strongly suggest that Mark is articulating an ideology of the land, and the revolutionary hopes of those who work it' (Myers 1988: 177). Understood as such, Mark 4:1-36 can be seen as a sermon on revolutionary patience (My'ers 1988:169).

\section{Construction of a new order (Mk 4:35-8:10)}

In this section, 'Mark's socio-literary strategy shifts from the symbolics of repudiation to the symbolics of reconstruction' (Myers 1988:188). In this regard Jesus' exorcism of the Gerasene demoniac (Mk 5:1-21) can be seen as Mark's establishing 'the other side of the sea as Gentile socio-symbolic space' (Myers 1988:190), an exorcism that implies political repudiation (Myers 1988:192), which also enables Jesus to commence his widespread ministry of healing to the poor to the Gentiles as well. Because the demoniac represents the 'collective anxiety over Roman imperialism' (Myers 1988: 193), Jesus' healing of the demoniac implies direct political repudiation. Myers 
(1988:194) also argues that, when this exorcism of Jesus is related to that of Mark $1: 21-29$, it is clear that Mark now has cleared the narrative space for the kingdom to commence in full: First in Galilee, now in Gentile territory. In this regard, Jesus' two crossings over the sea (Mk 4:35-41; 6:45-53) can be seen as Jesus' 'racial reconciliation' of Jews and Gentiles. Myers understands the two double healings in Mark 5:2143 (the daughter of Jairus and the woman who had been suffering from hemorrhages for twelve years) and in Mark 7:24-37 (the healing of the Syrophoenecian's daughter and the deaf man in the region of the Decapolis) in the same vein, namely that the kingdom must first be given to the outcasts: In Mark 5:21-43 the issue at stake is class status. Jesus is approached by Jairus, a member of the Jewish ruling class, but on his way to Jairus' house, a woman with no class and status is healed first. The same can be said of the two healings in Mark 7:24-31: In both cases Jesus reverses the status of Gentiles $^{34}$, Myers $(1988: 205)$ concludes his analysis of this section with the two wilderness feedings in Mark 6:33-44 and 8:1-9. These stories also represent the flowering of Mark's socio-economic ideology: The kingdom is a kingdom of economic satisfaction (Myers 1988:205).

\section{'Passion' tradition (Mk 6:14-29)}

According to Myers (1988:215-217), this narrative has three functions: First, Jesus again is typified by the narrator as the successor of John (Mk 6:14-15). Second, it serves as a prolegomenon to Jesus' anticipation of his own execution. And third, it also indicates that the political destiny of those who proclaim repentance and a new order will be the same. This also explains why the story of John is inserted by Mark into the narrative of the apostles' mission: '[I]insofar as they inherit the mission, they will inherit its destiny' (Myers 1988:217).

\section{Symbolic epilogue (Mk 8:11-21)}

The purpose of this epilogue is, according to Myers (1988:223), to give 'reliable commentary', offering the disciples/reader hermeneutical keys to the meaning of the preceding narrative of Jesus' symbolic action. By warning the disciples of the 'yeast of the Pharisees and the yeast of Herod' (Mk 8:14), Jesus is summarizing the political dis course of the first narrative: On the one hand, the Pharisaic party opposes integration on the grounds of social boundary and purity, and, on the other hand, the Herodian sponsored program of Hellenization offers a style of integration based on cultural imperialism and collaboration with Rome (Myers 1988:224). Jesus, however, is the 'one loaf' (Mk 8:14), all that is needed, 'enough for the journey to follow' (Myers 1988:226), However, because the disciples do not understand this, the narrative fulcrum follows (Mk 8:22-26), a story about Jesus' restoration of sight to the blind. 


\section{BOOK II}

\section{Prologue/Call to discipleship (Mk 8:27-9:13)}

The second prologue, as the first, begins on 'the way' (Myers 1988:235). In the first prologue, it was a way through the wilderness. Now, this is redefined as 'the way to Jerusalem'. Myers (1988:236) further identifies the following similarities between the first and second prologue: John as Elijah is referred to in Mark 1:6 and 9:11-13, Mark 1:2, 13 and Mark 9:2, both contain exodus symbolics, we find a divine voice in Mark 1:11 and 9:7, a call to discipleship is present in Mark 1:16-20 as well as in Mark 8:3436. Peter, James and John is central in Mark 1:16, 19 and in Mark 9:2, and finally, Jesus struggles with Satan in both Mark 1:12 and 8:33. Furthermore, Jesus identity now becomes clear: In relation to Peter's answer in Mark 8:29, Jesus is identified as the 'politically loaded term Messiah ... Jesus is not simply a great prophet; he is a royal figure who will restore the political fortunes of Israel' (Myers 1988:242).

\section{Construction of a new order (Mk 9:14-10:52)}

This section, according to Myers (1988:258), can be typified as a catechism by Jesus on nonviolence. In Mark 6:14-29, Mark already indicated that the political destiny of those who proclaim repentance and a new order will be the same of that of John. The disciples, by inheriting the mission, also inherited its destiny (Myers 1988:217). The followers of Jesus, therefore, must expect the fate of the subversive, but also the ultimate choice of the cross. The choice to take up one's cross implies the following: Those who are first must become last (Mk 9:30), patriarchal practices that drive a wedge into the unity and equality of the new community must not be allowed (Mk 10: $1-12$ ), the children, as 'the least of the least' must be put in the center of the new community (Myers 1988:267): In the new community both access and acceptance must be available to all. Also, there is no more place for economic class and privilege (Mk 10:17-31; Myers 1988:271). Finally, leadership-as-domination must not be part of the new community (Mk 10:35-45; see Myers 1988:280).

\section{Campaign of direct action (Mk 11:1-13:3)}

In this section, Jesus' long journey from the social and symbolic peripheries of Palestine to its center now becomes complete. In Mark 11;15-19, Jesus' direct action against the economic and political exploitation of his day reaches its climax: '[This] episode (Mk 11:15-19 - EvE) ... [is] the centerpiece in Mark's unrelenting criticism of the political economy of the temple. Jesus attacks the temple institutions because of the way they exploit the poor' (Myers 1988:299). Previously Jesus had repudiated the purity and debt systems themselves (and its marginalization of the 'outcasts'); now Je- 
sus calls for an end to the entire cultic system (Myers 1988:301). Jesus thus shuts down the temple, exactly because it has become a den of thieves: It robs the poor and results in class oppression (Myers 1988:302-307).

\section{Extended sermon (Mk 13:4-37)}

At the conclusion of the first campaign of direct action in Capernaum, Jesus withdrew to the sea to reflect upon his ministry in a sermon consisting of parables (Mik 4:1-34). Here at the end of the second direct campaign in Jerusalem, Jesus again withdraws, this time to teach his disciples how to discern and endure the end to come. The rebels were on the way to Jerusalem, and they were recruiting people in their plight (Mk 13:6-8). Jesus, however, is counter-recruiting. Why not aid and became part of the rebel cause? Because it was mere rebellion, the recycling of oppressive power in new hands. To journey deeper into history, to experiment with a political practice that will break the reign of domination in the world, the disciples must be prepared to suffer, that is, to 'take up the cross': They must practice nonviolent resistance (Myers 1988:343). However, this would definitely mean political persecution (Mk 13:9-13).

\section{'Passion' tradition (Mk 14:1-15;38)}

This part of the story can be divided into three main sections: The last days of community with Jesus (Mk 14:1-52), the double trial narrative (Mk 14:53-15:20), and Jesus' execution (Mk 15:21-38). The first section is comprised of four aspects: The leaders who seek to arrest Jesus, the leaders who recruit Judas as an informer, Jesus predicts that one will betray him, and Jesus predicts that all will desert him. The double trial narrative, according to Myers (1988:372-375), clearly indicates that Mark's narrative means to portray Jesus as convicted on charges of sedition by a Roman politicolegal process. Both parties in the colonial condominium, the Sanhedrin and the Romans, perceived Jesus as supremely subversive and a dangerous threat. He had to be eliminated at all costs, and therefore they cooperated with each other (Myers 1988: 374). At Jesus execution, during the moments of Jesus' life, Mark gathers together on stage all the characters in his political drama: Roman and Jewish authorities, the crowd, the disciples (in the background), and the rebels (represented by Barabbas and the two social bandits) ${ }^{34}$. But again, Jesus triumphs: When he dies, the sanctuary curtain was rent from top to bottom. 'The strong man has not prevailed, his 'house' has been ransacked' (Myers I988:390).

\section{Symbolic epilogue (Mk 15:39-16:8)}

In the second epilogue, the women become the 'lifeline' of the discipleship narrative (Myers 1988:396). It is they who hear the message from the young man that they must go and tell Peter and the other disciples that he will be found in Galilee (Myers 
1988:399). According to Myers this does not refer either to a parousia or resurrection appearance, but to a future point of reference in terms of a past one: Galilee, where the disciples were first called, sent on their mission and taught by Jesus. 'In other words, the disciple/reader is being told that the narrative, which appeared to have ended, is beginning again. The story is circular' (Myers 1988:399).

In addition to this main plot, Myers (1988:120-121) is of the opinion that in Mark we can also abstract three 'subplots': Jesus' attempt to create a new community (the object/target being his disciples), Jesus' ministry of healing, exorcism and proclamation of liberation (the object/target being the poor and oppressed, i e the crowds) and Jesus' confrontation with the dominant socio-symbolic order (the object/target being the Pharisees, Herodians and ruling Jerusa.lem clergy).

Furthermore, in reading Myers's commentary on Mark it becomes clear that Myers is of the opinion that the Gospel's profound and pervasive awareness of persecution should be attributed to three sources: Rome's persecution of its war in Palestine, the Jewish ruling classes' collaborationist politics ${ }^{36}$ and the Jewish rebels' attempts to recruit rural peasants to take up arm $s$ in the revolt against Rome ${ }^{37}$. Mark's community, Myers hypothesizes, was under severe pressure to take sides in this situation, and their option for non-alignment brought them under attack from all three powers. Though non-aligned, Mark's community was hardly non-involved: 'The narrative strongly suggests that Mark's community is in fact practicing some communal model (10:28) and experiencing social oppression because of it' (Myers 1988:442). This model was a revolutionary one in which Gentiles, women, and children were accorded positions of authority, respect and honor $r^{38}$.

In this new communal order, Mark teaches his community to accept the cross as Jesus did, and therefore the Gospel is firmly anchored in a living community's practice and experience of discipleship. The weight of their problems, however, threatened at times to crush the community, and therefore Mark repeatedly confronts his readers with failure in commitment to discipleship. In this situation, Mark shows us that Jesus himself is ever 'on the way' before them to guide and inspire their following and living in this new community (see also Blevins 1989:571-572; Curry 1989:30-31; Jurgens 1989:137-138; McAlister 1989:50; Walter 1989:761-763; Byrne 1990:242-247; Martin 1990:407-410; Malbon 1990:330-332; McVann 1990:42-43; Speech 1990:91-92; Swartley 1990:227-230; Talbert 1990:189-192; Domeris 1991a:307-309 for a more specific discussion of Myers' understan ding of specific texts in Mark).

\subsubsection{H C Waetjen}

In his social-political reading of Mark, Waetjen (1989) assumes that 'Mark's Gospel is a narrative world reflecting the career of Jesus in its original sociohistorical context, but nevertheless, a literary construct created by an anonymous author ....' (Waetjen 
1989:xii). According to Waetjen (1989:2-4), a hermeneutical perspective that will enable contemporary readers to become 'informed readers' (Waetjen 1989: 2), and possess the literary competence to actualize the encoded meaning in Mark, must consist of a synthesis of the following: Macrosociology as understood by Lenski (1966) and Lenski \& Lenski $(1982)^{39}$, the sociology of colonialism and sociology of millennialism as advocated respectively by Hollenbach ${ }^{40}$ and Burridge respectively ${ }^{41}$, and Iser's (1980:35-73) literary-critical 'theory of aesthetic response ${ }^{42}$ ' (see Waetjen 1989:ixxiv). More specifically, Waetjen employs historical sociology (as interpreted by Lenski 1966 and Lenski \& Lenski 1982 in terms of macrosociology) to locate the position and economic well-being of individuals, groups and institutions within the socio-economic pyramid of Roman Palestine, as well as their relationship to the means of production. This use of macrosociology will enable the 'informed reader' to see that class, race and sex consciousness played an integral part in the formation of the narrative (Waetjen 1989:x).

Waetjen further uses the sociology of millennialism for a better understanding of Jewish apocalypticism as well as phrases like 'the kingdom of God', that is present in the narrative. Finally, Iser's theory of aesthetic response is used to correct an 'authorially oriented intuitionist' reading of the text. It is thus clear that Waetjen attempts to read Mark from a perspective that combines sociology and literary theory. Also crucial to understand Waetjen's reading of Mark is his assumption that Mark is no window into historical realities pertaining to Jesus (Waetjen 1989:1), but rather an ideological construction addressed to, and reflective of, the lower-class Gentile peasants and artisans of Roman-occupied Syria. This lower-class peasants lived as an agrarian society and had to endure sharp social stratification and systemic oppression (see Waetjen 1989:710 for his interpretation of Lenski \& Lenski 1982 in this regard). Waetjen $(1989: x)$ also sees the setting of the Gospel of Mark as Syria, and dates it between 73-75 B C E.

In Part Two of his book, Waetjen offers his own translation of Mark to reproduce 'the rustic character of Mark's Greek' (Waetjen 1989;xi), and to give the reader an initial experience of interacting with the text ${ }^{43}$ (Waetjen 1989:27-62). Waetjen (1989:63251) then turns in Part Three of his book to an analysis of Mark's gospel by using macrosociology (as understood and described by Lenski 1966 and Lenski \& Lenski 1982), Burridge's sociology of millennialism and Iser's theory of aesthetic response (Iser 1980:35-73). This part Waetjen calls 'actualizing the semantic potential of the Gospel', of which a brief summary will now be given ${ }^{44}$. 


\section{Beginning the construction of the way (Mk 1:1-11)}

The Gospel of Mark tells the story of the construction of 'the way' (Waetjen 1989:63). It features the extraordinary career of Jesus, the Jew, 'from Nazareth of Galilee' whose unparalleled activity establishes once and for all a new road to life. In this regard, Waetjen (1989:67. 74) argues that Jesus' baptism by John (Mk 1:9-11) can be seen as a socio-theological watershed (see Black 1991:83) in the narrative. Three aspects of Jesus' baptism make it distinctive: First, he is the only Jew from Galilee to present himself for baptism by John at the Jordan (Mk 1:5), and thus is baptized as an 'outsider

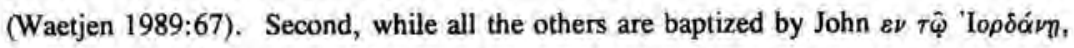

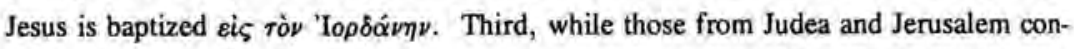
fess their sins while being baptized, this is not the case with Jesus' baptism, Jesus, therefore, alone submits to the full depth of John's baptism, and he alone expresses the repentance that God's forerunner, John, was demanding. In effect Jesus therefore drowned, or died eschatologically.

Following Burridge's interpretation of the sociology of millennialism, Waetjen (1989:69) sees Jesus' baptism also as a death in reference to Jesus' participation in the structures and yalues of his society, for example the pollution system of binary oppositions by which power is ordered in the Jewish Palestinian society. Wholly unobliged to the status quo ante, Jesus arises from his baptism as God's viceregent, the deified 'New Human Being', who will now inaugurate God's transformation of the world, and will reorder power in such a way that all injustice, exploitation and dispossessing will be destroyed.

\section{Temptation in the wilderness (Mk 1:12-13)}

Immediately after his baptism, Jesus is driven into the wilderness by the very Spirit that descended upon him. The wilderness is a reality of chaos and formlessness, and it is symbolic of the anarchy Jesus now confronts as a result of his experience of nothingness and his entry into a reordering of power. The new order, however, has not yet been constituted. By being tested for forty days in the wilderness by Satan, this new order is constituted: Like the Hebrews of old, who abandoned the unjust and exploitative Egyptian ordering of power and escaped into the bliss of unobligedness, Jesus is abandoning the moral order of Roman-occupied Palestine, which has become as oppressive and inhuman as the bondage that the Hebrews suffered in Egypt (Waetjen 1989:75). 


\section{Establishing God's rule (Mk 1:14-45)}

Jesus commences his work in Galilee with an ambiguous proclamation of the good news of God and an attendant call to repentance. The threshold of the long awaited reconstitution of all things has been reached. After calling disciples (a calling in which Jesus' authority to reorder power is shown), Jesus commences his work of restoration in the synagogue, a place which fostered the traditional values of Judaism (Mk 1:2129). By healing the demon-possessed, Jesus thus extends God's rule to include the diseased $^{45}$ and the demon-possessed (Waetjen 1989:84). Jesus' healing of the leper in Mark 1:40-45 has the same meaning: 'The millennial rule of God is being actualized for the masses of the poor, oppressed, diseased, and dispossessed people of Galilee' (Waetjen 1989:86).

\section{Reordering the world and conflict with the guardians of society (Mk 2:1-3:6)}

Mark 2:1-12 introduces a new aspect of Jesus' reordering of power; By forgiving the paralytic his sins, Jesus shows that he, as the New Human Being, has the power to forgive sins on earth. Jesus perceives that the man's condition of paralysis is the consequence of all the injustices, injuries and wrongs that have been done to and by this individual (Waetjen 1989:87). By forgiving him his sins, Jesus therefore proclaims that he redeems life by canceling the debts and obligations of the past that continue to determine human existence in the present. Jesus' calling of Levi and eating with tax collectors and sinners ( $\mathrm{Mk} 2: 13-17)$ also indicates that Jesus is not operating according to the purity code of the scribes. The binary oppositions of the Jewish pollution system do not determine his associations and relationships. The two concluding episodes of this narrative (Mk 2:1-3:6) also illustrate the reconstruction of the world or the reordering of reality to which Jesus is committed: By plucking grain on the sabbath (Mk 2:23-28), Jesus shows that genuine human need always has priority over regulations and institutions (Waetjen 1989:93). This is also true of Jesus' healing of the man with the withered hand on the sabbath (Mk 3:1-6). No laws nor patterns of habituation can be imposed to regulate his practice of justice (Waetjen 1989:94).

\section{Founding a new Israel (Mk 3:7-35)}

The narrator's summary of Jesus' ministry in Mark 3:7-12 reveals a society in which the process of redemption has broken down. The use and the control of power by the ruling classes are self-serving, orientated towards the preservation of the existing structures. This system has no integrity in that it engenders greater economical, political and social impoverishment among the masses of people. In this social turmoil and chaos, Jesus proceeds to establish a new community by appointing the twelve as the 
new Israel, a community that partakes in the privilege of the community equally (Mk 3:13-19; see Waetjen 1989:97). However, the scribes who have come down from Jerusalem maintain that Jesus is a tool of the devil (Mk 3:20-30). Jesus however indicates to them that by entering into a reordering of power, he has overpowered them and now is engaged in the liberation of the possessed and dispossessed (Waetjen 1989:99), that is, in creating a new community. In Mark 3:31-35 this new community is defined: It is a community that is based on a horizontally structured human interconnectedness, not on blood, ethnic nor racial lines (Waetjen 1989:100).

\section{Teaching in parables (Mk 4:1-34)}

In Mark 4:1-34, Jesus indicates that his teaching will be conveyed in the form of parables, stories that subvert the world (Waetjen 1989:100). The parable of the sower (Mk 4:1-20) indicates that Jesus' ministry is not to be judged prematurely, in that there will be loss, but also gains. In Mark 4:26-29, for example, the rule of God is compared to the activity of a peasant during an agricultural season, a collaboration is thus implied between human beings and the Creator that is comparable to the partnership between peasant and earth. Their independent activities will eventually produce a harvest of the realities that the reign of God brings: Justice, freedom, autonomy, health and the fullness of life (Waetjen 1989:107).

\section{Gradations of the authority of the New Human Being (Mk 4:35-5:43)}

A new phase of Jesus' ministry is opened in the section Mark 4:35-5:43 as gradations of the authority of the New Human Being are disclosed by a series of four events: The first event (Mk 4:35-41) indicates that the disciples do not after all know who Jesus is, and simultaneously throw their own identity into question (Waetjen 1989: 113). The second event occurs in Gentile territory: The Gerasene demoniac is possessed by many/Legion unclean spirits. As such, he is 'the representation of gentile '(dis)order' and (dis)integration' (Waetjen 1989:117). By healing him, Jesus therefore not only restored a human being, but also destroys two thousand swine, that is, the food supply of the Roman legions stationed in the territory. The last two events in this part of the narrative are that of Jesus' healing of the woman who had been hemorraghing for twelve years, and the daughter of Jairus who was twelve years old (Mk 5:21-43). The number twelve links the two women to each other and to the ethnic reality of the twelve tribes of Israel which the number intimates. The older woman represents traditionbound Israel and the young girl embodies the new Israel. Both of them are redeemed and therefore enabled to fulfill their destiny. 
Rejection in Nazareth and the rising need to prepare the disciples for their own ministry in the future (Mk 6:1-56)

In this section of the narrative, Jesus travels to his hometown (Mk 6:1-6). Jesus' present activities however are so discontinuous with the past in which the townsfolk of his hometown have imprisoned him, that they are uncertain that this is the same person who grew up among them, and therefore he is rejected. Jesus then sends out the recently appointed twelve in order to enter into his commission (Mk 6:7-13). When they arrive back from their own mission, Jesus uses the multiplication of the loaves to demonstrate to them the extent of their participation in his authority (Mk 6:35-44). Waetjen (1989:129-131) understands Jesus' walking on the sea (Mk 6:45-52) in more or less the same vein: Jesus' walking on the sea is not intended to prove his messiahship, but to display the capabilities of God in creating the new social order.

\section{Undermining the pollution system (Mk 7:1-8:11)}

Against the background of Jesus' popular ministry in and around Gennesaret, the narrator reintroduces the Pharisees and some of the scribes coming from Jerusalem (Mk $7: 1$ ). Their criticism of the disciples' conduct of not washing their hands before they eat implies that the disciples are in grave danger of losing their Jewish identity as it is defined by them. Jesus however answers them to indicate that the divine object should be to expunge the impurities from the heart in order to restore wholeness and social integration and to transform the world into a creation of the one and many (cf Mk 7:14 23; Waetjen 1989:133). Jesus then moves to Gentile territory and heals the daughter of a Syrophoenician woman because she, in contrast with the disciples, acknowledges his lordship (Mk 7:24-30; see Waetjen 1989:136). In the next episode Jesus heals a deaf man (cf Mk 7:31-37), and by the healing the man Jesus summons God's rule to come to the Gentiles (Waetjen 1989:137). In Mark 8:1-11 Jesus again feeds a crowd, this time a Gentile one, in which Jesus expresses his passion for the Gentiles that is also included in the new community of God (Waetjen 1989:138) 46 .

\section{Crisis in discipleship (Mk 8:11-9:50)}

In Mark 8:14-21 it becomes clear that the disciples do not understand who Jesus is, because they are not able to understand that the 'one loaf' ( $\mathrm{cf} \mathrm{Mk} \mathrm{8:14)} \mathrm{in} \mathrm{the} \mathrm{boat} \mathrm{with}$ them is Jesus, and that those who partake of this one loaf are joined together to form one body. This lack of perspicuity is mirrored in the following story of Jesus' restoration of sight to a blind human being in two stages (Mk 8:22-26; see Waetjen 1989: 142). The disciples' misunderstanding of Jesus' identity is also clear from Mark 8:2730: By calling Jesus the Messiah, Peter uses an essentially elitist title, namely that of a 
popular king that maintains his reign by collecting taxes and supporting an army (Waetjen 1989:144). If therefore, Peter's confession is to be retained, it had to be filled with a new content, and therefore Jesus predicts for the first time that it is necessary that the New Human Being had to suffer and be killed by the Jewish elite, that is, the elder, the chief priests and the scribes (Waetjen 1989:145). They will reject him and hand him over to the Romans for execution precisely because the rule of God which he is establishing will eventually abolish the moral order they attribute to divine origin and which is safeguarded with the power of capital punishment (Waetjen 1989: 145-146). However, if the disciples want to be God's representatives in the new community, they must become like children (Mk 9:33-37), thus people who have no status at all, who are, like children, lowly, weak and defenseless (Waetjen 1989:159).

\section{Entering Judea and constructing the way into Jerusalem (Mk 10:1-52)}

In Mark 10:1-12, Jesus is challenged by the Pharisees on his understanding of divorce. In his answer, Jesus indicates that separation and divorce are realities that originate from a pollution system which promotes inequality, oppression and exploitation (Waetjen 1989:166). Also, in the next episode (Mk 10:13-16), Jesus indicates that in their innocence and openness, children manifest the qualities of authentic humanness which are characteristic of God's rule (Waetjen 1989:167).

Entry into Jerusalem, negation of the temple institution, and confrontation with the ruling elite (Mk 11:1-12:44)

In this section of the narrative Jesus' most important action is that of his 'cleansing' of the temple. For centuries the temple had functioned as the control center of the tributary mode of production that appropriated the agricultural surplus of the peasants and redistributed it among the temple functionaries. In time, it became the central economic institution of Judea and of the entire world of Jewry. It was thus the pinnacle of oppression and exploitation in Palestine. By 'cleansing' the temple, Jesus made an end to all of this; his temple action 'marks the termination of its power and privilege, but especially its oppression and dispossession of the Jewish masses' (Waetjen 1989:183).

\section{Teaching on the last things (Mk 13:1-37)}

In Mark 13:1-37 Jesus teaches his disciples that all the institutional structures the Jewish elite had erected for the exploitation of the masses of humankind, all the socalled powers and principalities, established by the forces of imperialism, that by oppression and dispossession have diminished human existence, will be transformed (Waetjen 1989:201). 
The anointing of the Messiah and the beginning of the passion (Mk 14:1-52)

After Jesus is anointed by a woman as the Messiah (Mk 14:3-9), Judas Iscariot meets with the ruling elite to plan to kill Jesus (Mk 14:10-11). After having his last meal with his disciples (Mk 14:12-25), Jesus is arrested. Jesus' aggressive ministry of reordering power therefore will consequently end in his trial, crucifixion and death.

\section{The trials (Mk 14:53-15:20)}

Jesus' trials are a clear indication that the Jewish elite tried to find a way to eliminate Jesus as a threat to their maintenance of society. After his trial before the Sanhedrin, Jesus is taken to Pilate. While the Sanhedrin found Jesus guilty in terms of the offense of religious heresy, the accusation of Pilate, by asking if Jesus is the king of the Jews, is political. 'The political crime of revolt against the state has replaced the offense of religious heresy' (Waetjen 1989:227). Also the crowd is given the opportunity by Pilate to choose between Barabbas (who was in prison bound with the revolutionaries; see Waetjen 1989:230) and Jesus. Manipulated by the chief priests, they choose Barabbas (Mk 15:11). On a political charge Jesus is then led out to be crucified.

\section{The crucifixion, death, and burial (Mk 15:16-47)}

Throughout his Galilean career, according to the narrative world of Mark, Jesus had concentrated his ministry in the rural area, actualizing the reality of God among the peasants by his teaching, exorcisms and healing. Now at the end of his life, one of them, Simon of Cyrene, carries his cross (Mk 15:21; see Waetjen 1989:231). On the cross Jesus suffers in silence, for in his silent suffering Jesus maintains his solidarity with all of his fellow human beings, regardless whether they are for him or against him. The reality of God's rule is not a world of binary oppositions, but rather a world of the one and many. 'Jesus, the New Human Being as the One, does not surrender his identification with the Many, although at this moment he has been completely abandoned' (Waetjen 1989:234). Ironically, therefore, it is Jesus' integrity as the New Human Being that determines his fate.

\section{Witness to the resurrection and final instructions (Mk 16:1-8)}

Through the narrative's open-end (Mk 16:7-8), Mark's addressees are summoned once more to follow him along the way that leads from existential death (Jesus' baptism) to resurrection, that which empowers one to work, like Jesus, for a reordering of power, without any obligedness towards any current social codes and expectations. This reordering of power will inevitably lead 'toward the universalization of God's rule and the co-enthronement of all humanity with the creator' (Waetjen 1989:245). 
To summarize: According to Waetjen, the Gospel of Mark tells the story of Jesus' construction of the way from Galilee to Jerusalem. After his baptism, Jesus, as the New Human Being, establishes God's new rule by his healings, teaching and exorcisms. This reordering of society brings him in conflict with the guardians of society. Jesus, however, founds a new Israel, and goes on to undermine the Jewish elite's understanding of society in terms of pollution, oppression and dispossession. When Jesus enters Jerusalem, he closes down the temple, the institution that had functioned as the control center of the tributary mode of production which appropriated the agricultural surplus of the peasants and redistributed it among the temple functionaries, therefore, the pinnacle of oppression and exploitation in Palestine. Finally, Jesus is killed as a political revolutionary. However, through the narrative's open end, Mark's addressees are summoned once more to follow him along the way that leads from existential death to resurrection, that which empowers one to work, like Jesus, for a reordering of power.

\subsubsection{Summary}

The historical-critical investigations into the opposition of Galilee and Jerusalem in Mark, as discussed in sections 2.2.1.1 to 2.2.1.4, yielded the result that a theological, eschatological and geographical opposition, historically and socially speaking, may have existed between the centers of Galilee and Jerusalem in the time of Mark's composition of his Gospel. In general, therefore, these studies were motivated by a historical concern in connection with the composition of Mark's gospel.

In section 2.3, it was argued that the insights of Lohmeyer, Lightfoot, Marxsen and Kelber, concerning the opposition between Galilee and Jenusalem in Mark, served as stimuli for the literary-theoretical study of the structure of space in the Gospel of Mark. The main contributions of these scholars (see 2.3.2 to 2.3.6), are twofold: First, the text of Mark as a literary unit is taken more seriously. Second, as result of taking the text more seriously, these scholars brought a new and important aspect of the structure of space in Mark to the fore: The central aspect of Mark's spatial structure is that of 'the way' of Jesus from Galilee to Jerusalem. Understood as such, the opposition between Galilee and Jerusalem in Mark serves to highlight that 'the way' of Jesus (from Galilee to Jerusalem) can be seen as the central aspect of Mark's spatial structure. This way of Jesus is a way of suffering, a way of conflict between Jesus' activities in Galilee (ruling for God), and the Jerusalem religious leaders' evaluation thereof (ruling for oneself/themselves).

From our above discussion of the works of Belo (section 2,4.2), Myers (section 2.4.3) and Waetjen (section 2.4.4), it can be concluded that 'the way' of Jesus, as identified by the different literary-critics discussed in sections $2,3.2$ to 2.3 .6 , is a way of suffering because of a political opposition between Galilee and Jerusalem in the 
Gospel. According to Belo, Jesus was committed to subvert Palestine's economic system. Mark 1:1-15 programs Jesus' way in which this will take place: First in Galilee, then in Jerusalem and, after Jesus' death, again in Galilee. The chief obstacle to Jesus' program was temple-centered Palestine. Its pollution-code governing food, sacrifice and sex, supported the interests of the dominant class. Deuteronomy and the prophets had tried adding to it some concern over what human beings owed to each other. Their failure convinced Jesus that the whole temple-system had to be abandoned in favor of an ecclesia among the pagans.

Jesus begins his subversion of Palestine's economic system by healing, teaching and expelling demons. By this, he subverts the scribes' and Pharisees' understanding of the pollution system. When Jesus feeds the multitudes with only five loaves, he acts out his messianic message: Give all you have to fill the hungry, and there will be plenty for all. Eventually, it seems that Peter understands who Jesus is, by proclaiming him as the Messiah. However, because it is clear to Jesus that Peter still did not understand what he wanted to do, Jesus goes on to destruct the temple. Because of this subverting ministry, but especially because Jesus destructed the temple, he drew the authorities' hatred, and was killed. Jesus' attack on the temple therefore inevitably lead to his death. Understood as such, the opposition between Galilee and Jenusalem is a political one.

This is more or less the same conclusion that Myers arrives at in his political reading of Mark's gospel. According to Myers (1988:188), 'throughout the Gospel Mark is far more interested in articulating geo-social 'space' in terms of narrative symbolics than actual place names'. Using Malbon's term geopolitical space (see Malbon 1986a: 40), Myers argues that in Mark 1:1-20 it is indicated that Jesus' mission will take place in two opposite symbolic spaces: The temple and its representatives (Jerusalem) and the periphery and its representatives (the oppressed and marginalized in Galilee). Jesus' ministry was a 'war of myths' against the ruling elite. By exorcising demons, teaching and healings, Jesus, on Galilean soil, binds the strong man (ruling elite). In Mark 6:14-29 it becomes clear that John's political execution will also be Jesus' destiny, as well as those of his disciples. In Mark 11:15-19 Jesus' direct action against the economic and political exploitation of his day reaches its climax: Jesus shuts down the temple, the centerpiece in Mark's unrelenting criticism of the political economy of the temple. During the double trial narrative, it becomes clear that Mark's narrative means to portray Jesus as convicted on charges of sedition by a Roman politico-legal process. Both parties in the colonial condominium, the Sanhedrin and the Romans, perceived Jesus as a supremely subversive, political and dangerous threat. He had to be eliminated, and they cooperated to do so. Understood as such, the opposition in Mark between Galilee and Jerusalem is a political one. 
According to Waetjen, the Gospel of Mark tells the story of Jesus construction of the way from Galilee to Jerusalem. After his baptism, Jesus, as the New Human Being, establishes God's new rule by his healings, teaching and exorcisms. This reordering of society brings him in conflict with the guardians of society. Jesus, however, founds a new Israel, and goes on to undermine the Jewish elite's understanding of society in terms of pollution, oppression and dispossession. When Jesus enters Jenusalem, he closes down the temple, the institution that had functioned as the control center of the tributary mode of production that appropriated the agricultural surplus of the peasants and redistributed it among the temple functionaries, therefore, the pinnacle of oppression and exploitation in Palestine. Finally, Jesus is killed as a political revolutionary. However, through the narrative's open-end, Mark's addressees are summoned once more to follow him along the way that leads from existential death to resurrection, that which empowers one to work, like Jesus, for a reordering of power.

Before we turn to section 2.5, three positive remarks in regard to Belo, Myers and Waetjen's respective readings of Mark have to be made: First, it is also clear that Belo, Myers and Waetjen give attention both to the text and the social setting thereof. The possible advantage of this association will be discussed in section 3.3.2. Second, because they take the social setting of the Gospel seriously, they are able to translate Jesus' way in Mark into social terms. His way was a way of suffering because of the political opposition between Galilee and Jerusalem in Mark (as it is portrayed by the narrator). Davies (1983:64) articulates this aspect of Belo's reading of Mark (and therefore that of Myers and Waetjen also) as follows:

[Their] most positive achievement is likely to be [their] sure understanding of the socio-economic, political and religious environment of early Christianity, since such an understanding is basic to a (materialistic or otherwise) reading of Mark's gospel.

(Davies 1983:64)

More specifically, Cook (1990:376) is of the opinion that the most positive aspect of Waetjen's reading of Mark is that he 'attempts to see Mark in the context of its time, place and audience'. This is also the point of view of Wink (1991:251): 'On the whole ... Waetjen's attempt to locate Jesus within the sociological context [of the Gospel] is convincing, and his overall depiction of Mark's intention is excellent'.

Third, ideological-critical readings like that of Belo and Waetjen make the interpreter aware of the pragmatical dimension of interpretation, as well as the fact that the object/target of communication has to be taken more seriously. This means that, in the Jesus-story, as reported respectively by the different gospel narratives, the object/target 
of Jesus' acts and sayings in the embedded micronarratives, as well as in the macronarrative, but also the object of the narrator's communication, have to be highlighted more in our interpretation of the gospels. It sometimes happens that scholars who practice ideological criticism, in concerning themselves with the ideologies within the literary text itself, tend to create a self-reflection of exploited and manipulated readers, so that they can liberate themselves. When this is the case, the manipulated audiences in the text itself, that is Jesus' audience, do not get their rightful attention (see Van Aarde 1991b:17). While this is sometimes the case in Myers' analysis of Mark's story of Jesus, it cannot be said of the works of Belo and Waetjen.

\subsection{EVALUATION OF THE CURRENT DEBATE AND THE IDENTIFICA- TION OF RESEARCH GAPS}

In evaluating the current debate concerning the possible political meaning of Galilee and Jerusalem in Mark, it became clear that the three above mentioned schools of thought (historical-critical, literary-critical and ideological-critical) each operate with different sets of presuppositions that are worked out by reading Mark using different exegetical tools. The first question, therefore, that must be asked, is a methodological one.

In section 2.2.2, it was contended that the exponents of the historical-critical school's interpretation of the opposition between Galilee and Jerusalem were motivated by a study of historical concerns relating to the composition of Mark's gospel. The main emphasis of their works was therefore to try to answer the question as to why the Gospel was written. We further saw that from these historical presuppositions theological conclusions emerged. The general conclusion was that the opposition between Galilee and Jerusalem is best explained by a difference in an eschatological outlook.

In my opinion, the works (and consequent results) of these scholars were hampered by two methodological shortcomings: In the first place, their historical-critical analysis is overplayed and controlled by their theological understanding of the Gospel, that is, without a grounding in the socio-economical, cultural, political and religious realities of first-century Mediterranean society. Because of this, it was possible to draw theological conclusions from a historical-critical study of Mark. In section 3.3.2, it will be contended that the use of a social-scientific model to study the historical situation (and other aspects) in Palestine at the time of Jesus and Mark can overcome this obstacle.

Second, because of their historical interest ('why' the Gospel was written), the 'how' of the Gospel was neglected. By the 'how' of the Gospel is meant, for example, the intention of the narrator, the function of the narrative, the ideological perspective and the interest from which the narrative is narrated and the function of space, time and characters in Mark's story of Jesus. In short, therefore, these scholars did not take the 
form of the Gospel (as a narrative) seriously. In section 3.4.3, it will be indicated that this research gap can be overcome by a well-defined narratological model which not only takes the narrative techniques of Mark seriously, but also inter alia, makes provision for a method in which all spatial relations in any narrative can be studied responsibly. It is also because of this shortfall that the different exponents of the historical-critical school were not able to see that in Mark the meaning of all its spatial relations is more than just an opposition between Galilee and Jerusalem. We must mention, however, to be fair to Kelber (see again section 2.2.1.4), that he noted that other spatial relations in Mark were also important to understand the full implication and meaning of space in the Gospel of Mark.

Turning to the exponents of the literary-critical school's analysis of space in Mark, it was indicated in section 2.3.1 that they made two important contributions concerning the study of space in the Gospel: They took the text of Mark as literary unity seriously, and because of this they soon realized that there was more to the spatial relations in Mark than just the opposition between Galilee and Jerusalem. For them, 'the way' of Jesus was the most important spatial relation in the Gospel.

These contributions, however, also have their shortfalls. Van Iersel, for example, explicitly employs the insights of structuralism in his analysis of space in Mark (see Van Iersel 1983:48-50). This argument can also be leveled against the work of Malbon. Malbon's work, apart from the fact that it is a 'structural exegesis as a way of learning about Mark and about narrative space' (Malbon 1986a:1), also uses the hermeneutical theory of Lévi-Strauss. The problem, however, with the works of Van Iersel and Malbon is that, in employing structuralism to study space in Mark, the Gospel as an narrative act of communication does not receive its rightful attention. Structuralism, in its strict sense, tries to identify structures in texts. The effect of these structures, or the question of why the narrator is using this particular structure, however falls into the background. Where structuralism only asks the 'how'-question, the 'why'-question also becomes important when one takes the narrative techniques of the Gospels seriously (see Van Eck 1990:151-153; 1991b:1010-1013). Malbon and Van Iersel's textual analysis therefore can be complemented by a narratological analysis of the Gospel. In such an analysis, the effect the narrator wants to create with the different identifiable structures in Mark will come to the fore. Another point of critique against Malbon is that she works with a hermeneutical model (that of Levi-Strauss) that is not literary in its essence, which is drawn into the text to explain the different spatial relations in the text. In section 3.4 .3 it will be argued that a narrative itself produces a hermeneutical key to investigate the ideological perspective and interest of the narrator on the topographical level of the narrative. 
A narrative can (provisionally) be defined as follows: An author, by employing an implied author (narrator), communicates his ideological perspective and interest (pointof-view) ${ }^{47}$ on a particular story (which consists of time, space, character and events) in terms of a text to a reader (see Van Eck 1990:151; 1991b: 1011). Or, in Genette's (1980:30-32) terms: A narrative is a story (histoire) that is told in the form of a text (récit) to a reader. The story becomes text by way of the narration of the narrator, that is his/her particular ideological perspective (interpretation) of the story ${ }^{48}$ (see also section 3.3.5.2 for a more extensive discussion on the meaning of these terms). When one compares this definition of a narrative with the works of Rhoads \& Michie (see section 2.3.3), Petersen (section 2.3.4) and Kingsbury (section 2.4.6) the following comments can be made: In the case of Rhoads \& Michie (1982:35-42), Petersen (1980a:151-166) and Kingsbury (1989:31), the aspect of time in Mark is discussed thoroughly (especially by Petersen). The aspect of the ideological point-of-view of the narrator is only touched on by Rhoads \& Michie (1982:35-42) and in some way by Petersen (1980a: 155). Characterization in the Gospel is attended to by especially Kingsbury (1989:31118 ), but also by Rhoads \& Michie (1982:101-135), However, in reference to space in Mark, it is only Rhoads \& Michie (1982:63-72) that refer in some way to the possible importance that the spatial relations in Mark could have for an understanding of the narrator's ideological perspective and interest in his story about Jesus. Rhoads \& Michie's interpretation of the different spatial relations in the Gospel, however, lacks a comprehensive theory in relation to a responsible study of space on the ideological level of the text. This argument also relates to the studies of space in Mark as been done by Van Iersel and Malbon. To escape the web of structuralism in studying the ideological perspective (and interest) of the narrator on the topographical level of Mark's narrative, not only a well-defined narratological model is needed, but also a narratological model that paves the way for the possibility to study the different spatial relations in the Gospel (inter alia the possible political implications of the opposition between Galilee and Jerusalem) comprehensively. Such a model will also make it possible to control and verify its results.

The narrative models of Petersen, Rhoads \& Michie and Kingsbury, howe -2r, lack one more important aspect, that of an analysis of the social circumstances of the addressees of the Gospel as well as the social location of the Markan community itself. Rhoads \& Michie (1982;3), for example, state the following:

Once the unity of the story (that is its literary unity - EvE) is experienced, one is able to participate in the world of the story .... One can read and interpret Mark's gospel as a story independent from the real people and events upon which it is based.

(Rhoads \& Michie 1982:3) 
Or, in the words of Kingsbury (1989:1): 'One of the most important features of Mark's story is the world it conjures up'. From this it is clear that the narratological models of Petersen (section 2.3.4), Rhoads \& Michie (section 2.3.3) and Kingsbury (section 2.3.6) do not take the social historical circumstances of the act of communication of Mark's story seriously. It is thus postulated that one can interpret and read, for example, Mark's story of Jesus, without necessarily attending to the social situation, setting and circumstances of the intended target/addressees of the narrative. Although such a reading is indeed possible, it will be argued in section 3.3.2 that it can be complemented by a social-scientific analysis. The reason for the need of such an analysis is the fact that in any narrative, the ideological perspective and interest of the narrator is always directed at either a legitimation or correction of the addressees' understanding of their own historical situation (i e their understanding of their own symbolic and social universe; see sections 3.3.2, 3.3.6 and 3.4 for an explanation of the meaning and importance of these terms). Because a narrative wants to communicate, this communication between narrator and reader (addressees) by means of a text (narrative) can not be studied in full if this aspect of the narrative (the addressees' social/historical situation) is not taken seriously.

Malbon (1986a:40), for example, states that one of the suborders of the spatial structure in Mark is that of geopolitical space. Would that mean that the geopolitical spatial opposition in Mark between familiar and strange has political implications? And when, in her architectural suborder, she states that one of the oppositions is that between house and synagogue, what would this opposition refer to when it is read in terms of the social background of Mark's story of Jesus?

This lack in the narrative models of the described literary-critics discussed in sections 2.3.1 to 2.3.6 is versed by Matera (1987a:86-87), Barr (1988:86), Kee (1990a: 98 ) and Muddiman (1990:308) as follows:

So Petersen and other literary critics argue that the text should not simply be understood as a window through which the reader views the historical author and his or her contemporaries. The text is a world in itself apart from the author and the original audience for whom the author wrote .... To be sure, one can read the Gospel in order to discover something about the historical Jesus and the early Church (and for that matter of the original audience - EvE), but literary critics do not. When reading a text, they place the question of history in abeyance.

(Matera 1987a:86-87; emphasis in the original) 
Malbon applies general literary-criticism [and] structuralism ... to the Markan text - integrating the results of each into a general interpretation of Markan space .... Structuralist categories often seems arbitrary to me. Asking for Mark's 'theology' strikes me as anachronistic. A more overt use of social scientific categories would make some of the conclusions more convincingly.

(Barr 1988:86; my emphasis)

The book as a whole shows how urgent it is for interpreters of the New Testament to take with full seriousness the social setting of Jesus and the earlier church, and how inadequate it is to treat the narrative of the gospels as primarily a dramatic dialogue in which the meanings of the crucial terms are self-evident to participants and modern readers. The dynamic of Jesus' transformation of Jewish hopes and expectations for covenant renewal is thereby lost, and the fuller impact of the intention of Mark is missed.

(Kee 1990a:98; my emphasis)

Jack Kingsbury's [analysis of Mark] well illustrates the problems of 'the move back to the surface text'. All other issues ... like the historical setting and intention of the Evangelist .... are not just subordinated, they are virtually excluded. Mark is read 'naively' as a story.

(Muddiman 1990:308)

These remarks of Matera (1987a:86-87), Barr (1988:86), Kee (1990a:98) and Muddiman (1990:308), according to my opinion, verse the research gap that can be indicated in the above literary-critical (structuralist/narratological) studies of the opposition between Galilee and Jerusalem in Mark's story of Jesus. In my opinion, the consideration of the historical/sociological circumstances, beliefs, hopes and problems of the intended/assumed audience of Mark can complement the literary-critical readings of Van lersel, Malbon, Petersen, Kingsbury and Rhoads \& Michie. In section 3.3.2, it will be indicated that this can be done by using a well-defined social-scientific model to. study the social world of Mark.

The research gaps that exist in the works of the historical-critical and literarycritical schools as described in sections 2.2 and 2.3 , can thus be summarized as follows: The historical-critics did not take the literary unity of Mark (or its narrative techniques) seriously, and in their historical (re)construction of the ecclesia of Mark, did not make use of a well-defined social-scientific model for constructing the social world of Mark's addressees. The literary-critical school, however, did take the literary 
unity of Mark seriously. However, those who made use of structuralism as an exegetical model (see Van lersel and Malbon), lost sight of the narrative techniques of Mark, and by this, neglected the important aspect of communication between implied author/ narrator and implied reader/real reader. Also other important aspects of the text, such as the ideological perspective and interest of the narrator, the narrator's usage of time and characterization were neglected. The narratological analysis' of Petersen, Rhoads \& Michie and Kingsbury addressed most of the shortcomings of the structural approach. However, in each case their respective narratological models lack the possibility to study space comprehensively. Further, they also neglected the social situation in which Mark was created, in that they saw Mark only as a mirror in which the reader can find him/herself, and not also as a window which enables us to discover something of the historical situation in which the text was produced. In section 3.3.2, it will be argued that this possibly can be overcome if a narratological reading of Mark is complemented by that of a social-scientific reading of the text.

The first methodological starting point of this study, when the above mentioned research gaps are taken into consideration, can therefore be provisionally stated as follows: To read Mark as an act of communication, in relation to Galilee and Jerusalem as political settings in the Gospel, a narrative model must be used which not only takes the narrative techniques, the communication and the ideological perspective and interest of a narrative discourse seriously, but also the spatial relationships in the text. Because the intended/assumed addressees of the Gospel (i e their beliefs, symbolic and social universe, geographical context) are also important to understand the act of communication a Gospel wants to create, such a narratological reading of Mark has to be complemented by a social-scientific reading of the text. In chapter 3 , a possible relationship in which these two kind of readings can be implemented, will be discussed 49 .

Reading the Gospels by way of an association of a narratological and a sociological analysis, however, is not a new approach. The three ideological-critical readings described above (see section 2.4) are examples of such an approach: Belo combines Althusser and Balibar's understanding of historical materialism with Barthes' method of structural and textual analysis. Myers argues that his main theoretical starting point in reading Mark is a combination of an extrinsic and an intrinsic reading of the text (Myers 1988:31-38). To do this he uses Gottwald's socio-historical reconstruction of biblical Palestine in terms of class conflict, Horsley \& Hanson's analysis of the socioeconomic situation in biblical Palestine, Douglas' interpretation of the symbolic universe of early Palestine in terms of the concepts purity and pollution (extrinsic reading), and Yoder's theory of political non-violence, and combining it with Chatman's literary analysis (intrinsic reading). Also, Waetjen (1989:1-26) sees his socio-political 
reading of Mark as a combination of sociological and literary theory. This is done by using Burridge's sociology of millennialism, Hollenbach's understanding of the sociology of colonialism, Lenski and Lenski \& Lenski's macrosociology, and combining it with Iser's theory of aesthetic response.

In section 2.4 .5 , the positive results of these three readings, by combining literary and sociological analysis, were indicated: First, attention is given to both the text and its social setting. Second, because the social setting of the Gospel is taken seriously, Jesus' activities in the Gospel can be understood also in social terms. And third, such readings make the interpreter aware of the pragmatical dimension of interpretation, as well as the fact that the object/target of communication has to be taken more seriously. The results of these three ideological-critical readings of Mark therefore can serve as a starting point for an own ideological-critical reading of space in the Gospel. These ideological readings, however, have one important shortcoming.

In section 2.4.2, it was indicated that Belo's main methodological starting point in using the models of Althusser and Balibar, is that the economic instance (vis-a-vis politics, kinship and religion) can be seen as the dominant instance in any society (Belo 1981:7). Belo thus reads Mark by concentrating mainly on the economical institution in biblical Palestine (cf also Quesnell 1982:130-131; Rice 1982:70-72; Westphal 1982:37-38; Davies 1983:63-64; Krentz 1983:58-59; Scroggs 1983:473-47450). Myers, on the other hand, except for using Yoder's theory of political non-violence and Douglas' understanding of the symbolic universe of early Palestine, mainly uses Gottwald's socio-historical reconstruction of class conflict and Horsley \& Hanson's analysis of the socio-economic situation in biblical Palestine as a starting point for his analysis of Mark (Myers 1988:47-87). From this selection, it is clear that for Myers the politi$\mathrm{cal}$ (and economical) institution(s) can be seen as the most dominant in biblical Palestine ${ }^{51}$. Byrne (1990:245), for example, makes the following comment on Myers' reading of Mark:

Again, the 'totally political and economic' interpretation seems in many places hardly adequate. Myers finds 'nothing supernatural' in the two feeding episodes, for example. 'The only miracle' ... is the triumph of the economics of sharing within a community of consumption over against economics of autonomous consumption in the anonymous marketplace.

(Byrne 1990:245)

Waetjen, on the other hand, is more balanced in his approach in reading Mark. By using macrosociology, as advocated by Lenski (1966) and Lenski \& Lenski (1982), he is able to analyze Mark in terms of the socio-economic, political and religious realities 
of the intended/assumed addressees of the Gospel. Thus, by choosing macrosociology as one of his points of departure, it enables him to avoid reading the text from an ethnocentristic or anachronistic perspective (see again section 1.2 for the meaning of these terms).

However, in regard to the works of Belo and Myers, the following questions can be asked: Is it the case that the political and economical institutions were so important in first-century Mediterranean society as they try to indicate? Were there also other institutions in first-century Mediterranean society other than politics and economics? And if this is the case, was one more dominant than the others?

According to Malina (1986b:152-153) four (three) $)^{52}$ basic social institutions can be indicated in first-century Mediterranean society: Economics, culture (kinship), politics and religion. Malina further argues that, as a general rule, one of these institutions maintains primacy over the others in societal arrangements. Malina (1986b:153) formulates this general rule as follows:

In Christendom in the past, and in Islamic republics in the present, kinship, economics, and politics are embedded in religion, i.e., the norms of kinship, economics, and politics are determined by the religious institution: representatives of the religious institution rule their societies in one way or another.

(Malina 1986b:153)

Malina (1986b:153-154) goes on to cite examples where it is possible that either kinship, economics or politics also can maintain primacy over the other embedded ones. In some societies, like certain modern societies of today, economics as a social institution maintains primacy over the other institutions. It is also possible in some societies that the political institution can control the economical, kinship and religious institution. According to Malina, in most Mediterranean countries (like Palestine), the institution of kinship, by means of families and the pater familias of the family, maintained primacy over the other institutions:

[I]n ... most Mediterranean countries, religion, politics, and economics are embedded into kinship, I.e., the norms of religion, politics, and economics are determined by the kinship institution ${ }^{53}$. Here, well-bom parents rooted in the 'best' families control society in their role as patrons.

(Malina 1986b:15454)

That kinship can be seen as the dominant institution in first-century Mediterranean society, can also be deduced from the following remarks of Myers (1988:168) and Waetjen (1989:81): 
I have mentioned that kinship was the axis of social world in antiquity. The extended family structure determined personality and identity, controlled vocational prospects, and most importantly facilitated socialization. For Mark, then kinship is the backbone of the very social order Jesus is struggling to overtum 55 .

(Myers 1988:168)

In agrarian society, systemic structures such as kinship and its exchange system of redistribution, the temple and its priesthood, which legitimated them, were dominant realities that deprived the greater majority of the people of much, if not most, of their livelihood ....

(Waetjen 1989:81)

From the above citations, it is therefore clear that the research gap which exists especially in the works of Belo and Myers, is that their respective ideological-critical readings of Mark do not take the full social context of the text into consideration.

In trying to avoid the fallacies of ethnocentrism/anachronism and reductionism in the subsequent analysis of focal space in Mark's story of Jesus, the question will be asked whether the institutions of economics and politics indeed were so dominant in first-century Mediterranean society as Belo and Myers have indicated. This will be done in four ways: First, Mark will be studied as an example of an (advanced) agrarian society, as Waetjen did (see especially section 7.3). Second, it will be postulated that kinship can be seen as the dominant institution in an agrarian society (see section 4.2.8). Third, the relationship between kinship, as the dominant institution in an (advanced) agrarian society, and that of the institutions of economics and politics, will be discerned (section 7.3). And finally, the question will be asked whether the above mentioned ideological-critical readings took it seriously that a shift in relationship between these three institutions can be indicated when Mark is studied, not representing a simple agrarian society, but an advanced agrarian society. In an attempt to realize these four goals, the insights of the above discussed ideological-critical readings will be used where applicable.

To summarize: The above review of the current debate of Galilee versus Jerusalem in Mark's story of Jesus has identified/revealed the following research gaps: Historical-critical studies of this opposition neither took the narrative techniques/ literary unity nor the social background of the Gospel seriously. The literary-critics did take the literary unity of the Gospel seriously, but their respective literary models lack the ability to study space, as well as the ideological perspective and interest of the narrator comprehensively. Furthermore, they also neglected the social situation in which 
Mark was created, in that they saw Mark only as a mirror in which the reader can find him/herself, and not also as a window which enables us to discover something of the historical situation of the Gospel. It was maintained that these research gaps can possibly be addressed by reading the text in terms of an association of a narratological and social-scientific analysis. The narratological analysis to be used will enable us to take the narrative techniques of the text seriously and study space in a comprehensive manner, as well as to analyze the ideological perspective (and interest) of the narrator, By associating this narratological analysis with a social-scientific one, the social background of the text will also come into play. This association, as well as the development of a narratological model that will both enable a study of space and ideological perspective, will, methodologically speaking, be addressed in chapter 3 .

The second research gap was discerned when the three above mentioned ideological-critical readings were discussed, namely that of anachronism/ethnocentrism and reductionism. To fill this research gap, a social-scientific model that will hopefully enable us to avoid these fallacies, will be developed in chapter 4 . After these two following methodological chapters, the text will first be read in terms of emics (chapter 5) and then in terms of etics ${ }^{56}$ (chapter 6). The final conclusions in regard to the political opposition between Galilee and Jerusalem in Mark's story of Jesus will then be drawn in chapter 7 (section 7.2 and 7.4).

\section{ENDNOTES: CHAPTER 2}

1 This scheme does not pretend that a chronological development can be indicated between the historical-critical, literary-critical and ideological-critical studies of the opposition between Galilee and Jerusalem. Although it is the case that a certain continuity between these three approaches can be indicated (see section 2.4.5), this scheme is used for practical reasons: First, to make a concise review of the debate in regard to this opposition in Mark's story of Jesus possible, and second, to enable a delimiting of the research gaps in this past and present debate.

2 See again Van Luxemburg, Bal \& Weststeijn (1983:97) in section 1.1 for a definition of this term.

${ }^{3}$ Although not indicated by Lightfoot himself, his identified opposition between Galilee and Jerusalem as an opposition between the seat of the gospel (divine revelation) and relentless hostility and sin (buman rejection) clearly relates to Mark 8:33 where Jesus typifies Peter's

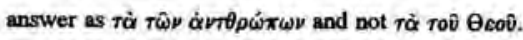


4 The difference between a socio-historical/historical-critical and social scientific analysis can be defined as follows: Historical-criticism emphasizes the social context, the social conditioning and the social Sitz im Leben of biblical documents (Elliott 1991 a:2). Historical-criticism collects data from biblical text to ascertain what was going on when and where, thus focusing upon "historical diachronic sequence rather than upon social synchronic interaction as well (Elliott 1991 a:4). Social scientific analysis wants to move beyond the collection of independent historical and social facts and investigates the interrelation of ideas and communal behavior, belief systems and cultural systems and ideologies as a whole, and the relation of such cuitural systems to natural and social eavironment, economic organization, social structures and political power. Understood as such, the social scientific study of biblical texts has two salient elements: First, it uses the social sciences to construct theories and models for collecting and analyzing data which illuminate salient features of ancient Mediterranean and early Christian society and culture. Second, it tries to elucidate the structure, content, strategy and intended rhetorical effect of the text within its social context. The text is analyzed as a vehicle of communication whose genre, structure, content, theme and aim are shaped by the cultural and social dynamics of the social system and the specific historical setting in which it is produced and to which it constitutes a specific response (Elliott 1989:5-6). The dynamics of the fact that all ideas, concepts and knowledge are socially determined are therefore taken into consideration much more and in a more social scientific manner in the social scientific study of biblical texts as bad been the case in the historical critical approach Van Aarde 1992b:437). This distinction between a socio-historical and social scientific analysis of biblical texts will be addressed in full in section 3.3.1.

5 This topographical structure of Mark was refined as follows by Van Jersel (1989:18-30) in his most recent work, Reading Mark:

Title

(Mk 1:1)

In the desert

first hinge

In Galilee

(Mk 1:16-8:21)

blindness to sight

On the way

blindness to sight

In Jerusalem

second hinge

At the tomb

(Mk 15:42-16:8)

What is thus added to the structure is what Van Iersel (1989:21-23) calls the two 'hinges' in the Gospel (Mk 1:14-15; 15:40-41), as well as Jesus' two healings of respectively the blind man in Bethsaida (Mk 8:22-26) and the blind Bartimseus (Mk 10:46-52). According to Van 
lersel (1989:21-22), both 'hinges' look forward and backward in the Gospel. Mark 1:14-15 gives a broad outline of what Jesus will do in Galilee, and also twice repeats the word Eiryensov that occurs in the title of the Gospel. The second 'hinge' tells the reader that the women who were watching the crucifixion from a distance, followed and served Jesus in Galilee, and at the same time, introduces the women who will play a leading part in the final part of the Gospel.

6 For a definition of the concept 'narrative point of view', as well as the way in which this concept is understood and employed in this study, see section 3.3.5 (especially section 3.3.5.2.4).

${ }^{7}$ Under the concepts of narrative world and narrative text, Petersen (1978a:49-80; 1980a:155161) understands the following: The narrative world is comprised of all events described or referred to in the narrative, but in their causal and logical (chronological) sequence, whereas the plotting of this world is to be seen in the ways its components have been selected and arranged in a sequence of narrated incidents. Understood as such, story time refers to the casual and logical sequence of the events in the narrative world, and plotted time as the sequence in which the causal events of the narrative world are plotted in the narrative text. Narrative text and plotted time are therefore plot devices of the narrator.

8 Vorster (1987b:203-222), for example, uses this insigbt of Petersen in regard to Mark 13 to argue that Mark 13 must be read as a narrated speech of Jesus. Building on Petersen's understanding of plotted time in the Gospel, as well his argument that Mark 13 has to be linked with the theme of incomprebension of the disciples in the rest of the Gospel, Vorster (1987b:221-222) argues that, from an apocalyptic perspective, the disciples are admonished to reconsider their position as followers of Jesus and encouraged to resist the persecution, tribulation and false messages of the false prophets and messiabs who will try to lead them astray.

9 Via (1975:71-170) has used a similar approach to analyze the plot of the Gospel of Mark. According to Via (1975:12), the plot/structure of Mark can be seen as a grid in which each narrative is given a horizontal or syntagmatic line of its own, and these syntagmatic lines are intersected by vertical or paradigmatic lines according to divisions proposed by the syntagmatic level of the text. The paradigmatic line of Mark is therefore 'the hidden or underlying configuration of the text that can offer some explanation for the more or less visible or obvious patterns in the text' (Via 1975:75). Using this approach, he argues that Mark came to be written because the kerugmatic proclamation, and faith in, the death and resurrection of Jesus reverberated in the mind of Mark and activated the comic genre whose nucleus is also death and resurrection. One recurring pattern which is found again and again in Mark is one which produces the four following steps: An act of initiative, persistence through conflict, death and 
resurrection (Via 1975:117). This pattern, according to Via (1975:158), can be detected in both the story lines of Jesus and the disciples in Mark's gospel. In terms of Jesus' relationship to his disciples, this underlying/paradigmatic structure surfaces on the syntagmatic level of the text as follows: Jesus calls and chooses his disciples, they fail to recognize who he is, then they misconceive his nature, finally they abandon him and Jesus therefore irrevocably repudiates the disciples. However, in terms of the underlying paradigmatic structure of death and resurrection in the text, the 'death' of the disciples will lead to their 'resurrection'. Although the disciples are therefore repudiated on the syntagmatic level of the text, from the paradigmatic level it is clear that their situation is not hopeless (Via 1975:158-161: see also Barclay 1975:65-66; Crossan 1976:486-487; Doty 1976:168-170; Kingsbury 1976:111-112; Williams 1976:88-90 for a more comprehensive summary of this point of view of Via). In more or less the same vein, Vorster (1980a:126-130; 1987a:68-74) argues that one of the prominent threads in the texture of Mark is following, or discipleship. According to Vorster (1987a:69) Mark's representation of the disciples can be seen as a literary attempt to prompt the reader to prepare for discipleship and to make it clear that discipleship is no easy task. Because of this, discipleship is portrayed in the Gospel in both a positive and a negative way, in that Jesus' disciples both follow and betray him. In this regard, Mark 8:29 can be seen as the turning point of Mark's narrative. In Mark 1:16-8:26 (in Galilee), the disciples had followed Jesus, but after Peter's answer to Jesus in Mark 8:29, it became clear that the disciples do not understand who Jesus is. Understood as such, there are two story-lines in the Gospel in regard to Jesus' relationship with the disciples: Jesus' 'success' in Galilee, and his 'failure' in Jenusalem. According to Via (1975:113-158) and Vorster (1980a:126-130), however, the plot of Mark is also structured in terms of two other opposing semantic lines that are in constant tension with each other, but are nevertheless developed simultaneously. The first semantic line can be described as the endeavor of the protagonist, Jesus, to complete his mission successfully; this mission is the manifestation of God's reign. The second semantic line can be described as the endeavor of the antagonist, the Jewish leaders, to achieve success in their objective of protecting the religion of the day (Judaism). The latter objective meets with apparent success when Jesus is crucified, but it is frustrated by Jesus' resurrection. Initially the plot unfolds in favor of the first semantic line. However, in Mark 8:27-33 there is a turning point in the success story. Peter acknowledges Jesus as the Christ, but fails to comprehend that the Christ must suffer. This they only understood after Jesus' resurrection.

10 Malbon (1986a:2-3) therefore argues that Mark contains a mythic structure because of the fact that the three spatial suborders she identifies in the Gospel subvert the expectations of the reader and therefore reflect the parabolic nature of Mark. In this regard, Cross (1975:59) argues that the parables in Mark function as myth, in that they subvert the expectations of the reader. 
11 To Kingsbury's narratological analysis of Mark can be added that of Breytenbach (1985). However, Kee's (1990ka:98) critique on Kingsbury's analysis of Mark, namely that it lacks a sociological analysis to' make it results more convincing, also holds true for Breytenbach's narratological analysis of Mark, as well as my own previous studies of space in Mark's story of Jesus (see Van Eck 19910, 1991b).

12 Van Aarde (1986a: $62-75)$ argues that in the Gospel of Matthew, it is also possible to discern two story-lines, nuamely that of Jesus and the disciples. Van Aarde, however, clearly spells out the narratological theory he is using to indicate these two story-lines in the Gospel of Matthew by making use of the insights of Lammert (1972:21-44) and Tannehill (1980:60-62). Lammert (1972:21) argrues that a narrative consists of a beginning, a middle and an end, that is, a Handlungsstrang. According to Lammert (1972:21) it is however also possible that a narrative can consists of more than one Handlungsstrang (for a more elaborate explanation of Lammert's point of vieww see Van Eck 1990:104-107). In regard to Mark, Tannehill (1980:6062), argues that two story-lines can be indicated: That of the commission of Jesus and that of the disciples. By using: these insights, Van Aarde (1986a:62-75) argues that the two storylines in Matthew are that of the Jesus-mission and that of the mission of the disciples, and that the relationship between these two story-lines is that of analogy. Van Eck (1988:139-149; 1989:778-800; 1990:17ק-183) uses these insights of Lammert, Tannehill and Van Aarde to indicate, in the same veiin as Kingsbury, that also in Mark these same two story-lines can be indicated. The difference between Kingsbury, on the one hand, and Van Aarde, on the other hand, is that the latter s:pells out the narratological theory that is used to discern these two story-lines in the Gospel of Matthew.

13 That Lohmeyer, Lightfoot, Marxsen and Kelber's insights in regard to the opposition between Galilee and Jenusalem served as stimuli for the works of Van Iersel and Malbon is especially clear from the fact that both Van Jersel (1982a:117) and Malbon (1982:242-244) take the insights of these scholars as their starting point for their respective analyses on this opposition in the Gospel of Mark.

14 Although not stated as such by Petersen himself, this remark of Petersen relates to Mark 10:41-45, where Jesus defines lording over one another in terms of service.

15 By epistemological crisis, Belo (1981:2-3) understands the following: Modern biblical scholarship tends to practice theology from the concept of faith. This is a symptom of the grip that traditional theology st ill has on the discourse of modern theology, namely to read biblical texts in terms of ancient dichotomies such as body/soul, transcendence/immanence or God/world. By doing this, modern biblical theology leaves out of consideration other important phenomena that relate, for example, to economics and politics. What is therefore needed is a study of faith in political and economical terms. 
16 The word 'praxis' is normally used in regard to historical materialism (Belo 1981:2). He, however, opts for the term practice, without given any reason for his choice.

17 Structural analysis sets out to 'describe and classify the infinite number of texts' (Barthes 1966:2-3). Textual analysis, on the other hand, involves the study of a single text down to the last detail: The 'structuration' of a single text is studied with its differences from others, with the plurality of its meanings, that is, by concentrating on the textual production that is going on the text, the work as a writing (Barthes 1974:12-13). According to Belo (1981:92-93), he wants to use both kinds of analyses of Barthes: On the one hand, his main aim is to do a textual analysis of Mark, but, on the other hand, while doing it, he wants to keep Barthes' structural analysis in mind. According to Belo (1981:93), this will enable him to delimit in what sense Mark as text differs from other texts.

18 The concept historical materialism refers to an interpretation of history that focuses on material realities in societies such as economic exchange, how money functions, who controls money in society, and how money is used (Althusser 1969:24). Dialectical materialism, on the other hand, refers to Marx's 'materializing' of materialism by defining it in terms of class: By using Hegel's dialectic of thesis, antithesis and synthesis, Marx sees the thesis as the classless subasiatic mode of production, the antithesis as socialism (which is a society based on class distinctions), and the syrthesis as communism (a classless society; see Althusser 1969:33).

19 In any social structure the economic base is dominant, the 'false consciousness' in Marx's terms (Balibar 1970:204). This economic base is kept intact by specific legal and political forms, which again are the product of ideologies that legitimate these legal and political forms.

20 According to Domeris (1991a:306), Belo's work is divided into three parts. It is, however, not clear what decides this argument.

21 These two narrative lines in Mark, which Belo (1981:152-155) calls the sequence of the loaves (the sequence of Jesus) and the sequence of the twelve, concur with the story-lines of Jesus and the disciples as has been identified by Via (1975:117), Tannehill (1980:60-62) and Van Eck (1988:139-149; 1989:778-800; 1990:177-183). See again end notes 9 and 12 of this chapter.

22 According to Horsley \& Hanson (1985:xiv-xvi, 48-51), the Zealots as a movement only came into being in 66-67. CE during the Jewish War. Before the Jewish War, however, social banditry (as a pre-political form of rebellion) was common in Palestine. In terms of this point of view of Horsley and Hanson, Belo's understanding of Jesus as trying to show his disciples that his mission is not of the zealotic type has to be understood in terms of social banditry. 
23 The temple-conomy in the first-century Mediterranean world was that of redistribution (Oakman 1991 a:35). Redistribution involved the politically or religiously induced extraction of a percentage of local production (i e from the peasants), the storehousing of that product, and its eventual redistribution for some political end or another. The redistribution-system of the temple thus was exploitative in terms of those for whom the produce was intended, namely the widows and the poor.

24 In this regard, Belo's reading of Mark is, to my opinion, reductionistic (see again section 1.3 for the definition of this term). In sections 4.2.6 and 6.4.4 it will be indicated that Jesus' activity of the hands also relates to Jesus' activity of healing, that is, to restore ill persons back to the position of being part of society and the household.

25 Myers (1988:4) argues that, in historical criticism, hermeneutics has the task of creating a critical distance between text and interpreter. However, 'the problem here is that critical distance was understood as detachment, the goal being an allegedly 'objective' assessment of the text' (Myers 1988:4; emphasis in the original). According to Myers (1988:5), this hermeneutical theology has been challenged by liberation theology. The axiom that praxis must predicate theological reflection, when applied to biblical interpretation, brought us to critical awareness of the dominant ideologies and social structures that shape the world in which we live. From this interaction we emerge with a fresh interpretation of the Bible. Myers thus refuses to abide by the 'typical' distinction between 'religious' and 'political' modes of discourse (Myers 1988:5). Because the present crises in modern society have everything to do with the ordering of power, the distribution of wealth, and the global plague of militarism, the Bible sbould therefore be read with social, political and economic questions in mind (Myers 1988:8).

26 In section 2.3.5, it was indicated that Malbon (1986a:2-3) argues that Mark contains a mythic structure, because of the fact that the three spatial suborders she identifies in the Gospel, subvert the expectations of the reader and therefore reflect the parabolic nature of Mark. The term 'myth structure' thus refers to 'an underlying spatial structure of binary oppositions' that, in terms of the paradigmatic structure of the text, replaces the syntagmatic (surface) structure of the text. Myers (1988:16), on the other hand, understands the term myth to refer to 'a kind of meaningful symbolic discourse within a given cultural and political system'. Myers thus understands myth in terms of the sociology of knowledge's understanding of the concepts of the symbolic and social universe. According to Petersen (1985: $\mathrm{x})$, the concept symbolic universe has to do with the overarching cognitive systems (i e ideology, mythology and cosmology), the systems of knowledge, belief and value that define certain groups' identities and motivate their actions. Understood as such, myth can be seen as the social counterpart of mythology (symbolic universe). Myers' 'was of myths' thus would relate 
to Jesus' understanding of the symbolic universe (of which God is part) against that of, on the one hand, the Pharisees, and, on the other hand, the scribes, Sudducees, chief priests and elders (temple hierarchy).

27 Yoder (1972:13-23) argues that, although it may be the case that a reading of the New Testament might well yield broad ethical or political principles, such as economic justice or human dignity, it should not, however, be looked to for practical instructions on how to achieve these objectives in our modern social systems. Any direct appropriation is naive, which means that it is up to the modern social ethicist to translate the abstractions of the New Testament into contemporary imperatives. For Yoder (1972:23-25), the crux of Jesus' political principle was his practice of pacifism/nonviolence. This pacifism, according to Yoder (1972:26-27), must not be seen as a consequence of Jesus' eschatological view on history, or as a well-intentioned but misguided perfectionism that could only wreck havoc in the real political world. Such an interpretation divorces principle from practice, or ends from means in terms of Jesus' practice. The Jesus story is normative precisely on the question of means, or practice, providing a paradigm for redemptive, nonviolent approaches to social and interpersonal conflict. Understood as such, Jesus' practice of nonviolence, as articulated in the call to 'take up the cross, was not pacifist at all, it intended a radical change to the structure of the society in which Jesus lived (Yoder 1972:28).

28 See again section 2.4.2 for Gottwald's socio-historical construction of biblical Palestine in terms of class conflict, that is, the opposing pollution and debt system which created class conflict.

29 Horsley \& Hanson's (1985) analysis of the socio-economic situation in biblical Palestine is done more or less from two perspectives, namely politics and economics. They explain, one the one hand, how peasant economy welfare went from bad to worse with Roman rule and Jewish aristocratic exploitation (Horsley \& Hanson 1985;1-47), and, on the other hand, the emergence of social banditry (as a pre-political form of rebellion) as a response to this economical/political oppression (Horsley \& Hanson 1985:48-69). Part of this social banditry was inter alia the royal pretenders and popular messianic movements (Horsley \& Hanson (1985:134) as well as popular prophets (Horsley \& Hanson 1985:135-187). One of the main points they are making is that the Zealots must be seen as a group that only came into existence in 66-67 CE, that is, during the Jewish War (Horsley \& Hanson 1985:xi-xviii).

30 The process of ordering a socio-cultural system is called 'purity', in contrast to 'pollution'. which stands for the violation of the classification system, its lines and boundaries (Douglas 1966:13-14). The study of purity is therefore the study of symbolic systems (Douglas 1966:34). Douglas (1966:18-22) understands the concept of purity as having two meanings: 
One the one hand, groups normally have a general system of purity by which their society is classified and structured. On the other hand, however, one may also speak of the specific purity rules and norms of a given group. Ancient Jews, for example, had specific purity rules which classifies foods as clean or unclean, which ranked objects according to degrees of uncleanness, and which identified persons as fit or unfit to enter the temple in Jerusalem. By these specific rules people and objects were thus declared sacred/profane, clean/unclean or pure/polluted. According to Douglas (1966:34-35), the term purity is best understood in terms of its binary opposite, namely 'dirt'. When something is out of place or when it violates the classification system in which it is set, it is called 'dirt' (Douglas 1966:35). For a more comprehensive discussion of Douglas' understanding of the symbolic universe of early Palestine in terms of these concepts, see section 4.2.7.

31 According to Chatman (1978:26), any narrative consists of a what (content) and a how (expression); in other words, a content that is expressed in a certain way by the narrator. The content of a narrative consists of events and existents (characters and settings). The how of a narrative (its form of expression) is studied at three levels: The story as a whole, the individual elements and episodes, and the internal composition of individual elements. For a more comprehensive discussion on Chatman's literary approach, see Van Eck (1990:23-25, 126130).

32 According to Holzner (1972:157), '[a]ny dominant ideology, especially one maintained defensively by a group threatened by change or by hostile forces, tends to emphasize collective identities and group boundaries'. Groups that find themselves in such a situation, Holzner argues, always react in one of three ways, that is, the subversive strategies of the escapist, loyalistically radical or confrontative/alienative. When a group resolves its conflict with the dominant order through disengagement, like the Essenes, their renewal/subversive strategy can be called escapist, Loyalistically radical groups, on the other hand, seeks structural change for the purpose of restoring or purifying traditional values. According to Holzner (1972:159), the advocates of the so-called Fourth Philosophy (see also Saldarini 1988:108, 124) which were essentially restorationist and retrogressive falls in this category. Finally, the confrontative/alienative stance applies to those groups who are critical of the dominant socio-political institutions, but refuses to pursue a reformist strategy, and thus becomes politically passive. The Galilean peasantry would fall in this category (Holzner 1972:160).

33 In this regard, Vorster (1985:27-66; 1987b:203-222) has convincingly argued that Mark 4 and Mark 13:3-37 has to be read as narrated speeches of Jesus. Myers' interpretation of these two narratives in Mark as extended sermons therefore concurs with Vorster's point of view.

34 The way in which class functioned in first-century Mediterranean world will be discussed in section 7.3.2. 
35 In this regard, Myers has failed to see that the Pharisees, as one of the groups that Jesus 'politically' opposed and subverted on Galilean soil, are not present in the latter part of Mark's story of Jesus, that is, after Mark 12:18.

36 For a comprehensive discussion of the relationship between the Roman elite and the Jewish elite (Sadducees, high priest, chief priests, scribes and elders), see Saldarini (1988:35-50). See also section 7.3.3 in which Saldarini's work in this regard is taken up.

${ }^{37}$ In this regard, Myers clearly makes use of the work of Horsley \& Hanson (1985), although it is not stated so by him.

38 Honor and shame as pivotal values in first-century Mediterranean world will be discussed in section 4.2.1.

39 The works of Lenski, Power and privilege: A theory of social stratification (1966) and Lenski \& Lenski, Human societies: An introduction on macrosociology (1982) divide human societies into two groups, namely pre-industrial and industrial societies. Preindustrial societies as such developed from being hunting and gathering societies, then became horticultural societies and finally agrarian societies. In terms of agrarian societies, the Lenski's located the different individuals, groups and institutions within the socio-economic pyramid of Roman Palestine, to determine the extent of their socio-conomic well-being, and to ascertain their relationship to the means of production (see Lenski 1966:284; Lenski \& Lenski 1982:177230). The concept agrarian society, as well as the distinction between simple agrarian and advanced agrarian societies will be dealt with in section 4.2 .8 , but especially in section 7.3

40 The sociology of colonialism understands demon and demon-possession as the result of colonial oppression and domination (Hollenbach 1982b:567-588; cf also Kiev 1964:135-137. 204-205, 262-263; Lewis 1971:35; Bourguignon 1976: 53-54). Understood as such, demonpossession can be caused by social tensions such as class antagonisms rooted in economic exploitation, or by conflicts between traditions where revered traditions are eroded. According to Fanon (1963:250), colonialism was a systematic negation of the other person and a furious determination to deny the other person all attributes of humanity, in that it forces the people who is dominated to ask themselves constantly the question of 'In reality, who am I?' In the colonial situation of domination and oppression it is therefore not strange that mental illness/spirit possession nourished in extraordinary numbers of the population ( $\mathrm{f}$ also Myers 1988:141-152, 1992:1-13; Waetjen 1989:113-119). However, in terms of the sociology of colonialism, demon possession can also be seen as a socially acceptable form of oblique protest against, or to escape from, oppression (Fanon 1963:290; Kiev 1964:218-219; Lewis 1971:72; Ward \& Beaubrun 1980: 206). Understood as such, some types of demon possession become escapes from, 'cures' for, as well as symptoms of social conflict. To adapt to stress in the 
midst of conflict, possession was seen as a socially recognized and accepted practice. Posses: sion thus functioned as a outlet for people who saw no other way to cope with the horrendous social and political conditions which they found themselves in.

41 Millennial movements are movements of oppressed and dispossessed people who reject the present moral order and look forward to the terrestrial reality of a new heaven and a new earth (Burridge 1969:10-11), In such a situation normally a prophet emerges and becomes the representative of the new human being for the new moral order that is anticipated (Burridge 1969:15-17; see also Crossan 1991a:159-167). From Crossan's description of millennialism (see Crossan 1991a:161) it can be deduced that millennialism, as described Burridge above, can also be understood as apocalyptism.

42 Iser's theory of aesthetic response can be summarized as follows: When reading the syntagmatic level of a text (i $\mathrm{e}$ its surface level), the reader is confronted by certain 'gaps' in the story, for example, missing information not given by the narrator, certain information that eventually does not fit in the story line, certain information that seems to be important are not given, or the bringing in of new perspectives on or characters in the story that makes it difficult for the reader to follow the story he is reading comprehensively. On the paradigmatic level of the story (its deep structure), certain norms and values that are communicated by the narrator for example are not understood by the reader, or challenge his own norms and values. In the end, however, the narrator leads the reader to accept his understanding of, for example, the society he is describing, and the reader corrects his previous understanding thereof. The aesthetic form of the texts thus led the reader to respond to it in the manner the narrator wanted the reader to. Iser's theory of aesthetic response thus in its essence consists of an interplay between narrator and reader (for a very comprebeasive, although concise, summary of Iser's theory see Koopman-Thurlings 1984:398-4I1).

43 Waetjen's translation of Mark has been received positively by many scholars. Wink (1991:249-250), for example, typifies Waetjen's translation a 'fresh vernacular translation of Mark. It is literal and it is awful - and that is what it makes so effective. He has succeeded in most conveying the colloquial, twangy rustication of Mark's homespun dialect'. Wink $(1991 ; 250)$ is also of the opinion that with this translation, Waetjen succeeded to indicate that Mark's gospel was not only a book about the lower classes, it was a book for them, in their own tongue. For a similar positive evaluation see Cook (1990:376-377).

44 As was the case in section 2.4.2 and 2.4.3, when Belo's and Myers' respective analyses of Mark were discussed, the following summary does not pretend to be exhaustive, but only intends to give a summary of Waetjen's main line of argument. 
45 According to Pilch (1981, 1985, 1988b, 1991, 1992), one bas to distinguish between disease and illness, of which the former can be seen as a modern interpretation of sickness. Understood as such, the man that was demon-possessed has an illness, not a disease. Pilch's point of view in this regard will be discussed in full in section 4.2.6. Waetjen's interpretation of Mark I:2I-29, however, indicates that he understands the demon-possessed man as having an illness, although it is not explicitly expressed so.

46 Recently Horsley (1992:10) has argued that the ethnic mix in Galilee was not Jewish, since '[n]othing in the Gospel of Mark itself ... suggests that Galilee was Jewish' (Horsley 1992:10). This argument of Horsley is based on first, the fact that there is only one reference to the term Ioudaioi in the Gospel (cf Mk 7:3), and second, on the fact that the term 'gentiles' (ethne) does not occur in the narrative of Mark. Be that as it may, from Mark 7:24 and 31 it is clear, at least from the narrative world of Mark, that the narrator depicts Jesus as feeding a crowd in Gentile territory.

47 The term ideological perspective (interest) or point of view has two components of referential meaning, that is, ideological and technical. Under the term ideological is understood the narrator's ideology as a network of themes and ideas that occur in a narrative as an 'imagined' version of a specific reality. The technical aspect of point of view refers to the way in which this ideology is structured in the text by the narrator. This is done by the narrator, for example, by structuring space and time in a specific manner in the narrative text.

48 Under the term récil is understood the narrative text itself (e $\mathrm{g}$ the Gospel of Mark). This narrative text, however, is a specific interpretation of histoire, a story (e $\mathrm{g}$ the story of Jesus). The term narration refers to the narrating activity of the narrator, that is, the narrating (retelling) of the story/histoire so that it becomes a récit/narrative text. Or, stated differently: Narration turns histoire into récit.

49 In regard to a literary reading of a text combined with a social scientific analysis, Waetjen (1989: $\mathrm{x}$ ) makes the following remark:

A hermeneutical perspective that is brought to bear on texts originating in another sociocultural 'world' without being informed by the disciplines of sociology, cultural anthropology, and an appropriate literary criticism is doomed to misconstruction and misinterpretation.

(Waetjen 1989:x)

50 In the different reviews of Belo's book (see Quesnell 1982:130-131; Rice 1982:70-72; Westphal 1982:37-38; Davies 1983:63-64; Krentz 1983:58-59; Scroggs 1983:58-59), an almost unanimous conclusion in this regard is reached: Belo, by 'using Marx to read Mark' concentrates mainly on the economical institution as the dominant institution in Mark to interpret the Gospel. 
51 In this regard, Jurgens (1959:137) and Byme (1990:243) call Myers' reading of Mark 'a political hermeneutic'. In mon or less the same vein, Blevins (1989: 571) is of the opinion that, because 'Myers feels thal one must read Mark through the lens of the grave political questions of our day', Myers's eading of Mark can be typified as a political reading. This isq also the point of view of Curry (1989:30-31), McAlister (1989:50), Walter (1989:761-763), Byrne (1990: 242-247), Martin (1990:407-410), Malbon (1990:330-332), McVann (1990:4243), Speech (1990:91-92), Swutley (1990:227-230). Talbert (1990:189-192) and Domeris (1991a:307-309).

52 In this regard, Malina (1981:54-55; 1989:131-137) is of the opinion that it can also be argued that only three social insitutions, namely the political, cultural and economical, can be discerned in first-century Medituranean society, thus leaving out the social institution of religion. According to Malina, relinion forms the meaning system in a society, and as such, feeds backwards into kinship, economs and political systems, unifying the whole by means of some explicit or implicit ideology. Suce both arguments, according to Malina (1988a:131), do not exclude each other, it will be aceepted here that three basic social institutions can be indicated in first-century Mediterranean ssciety, with religion embedded into politics, economics and kinship. This feature of first-cenury Mediterranean society will be attended to in a more comprehensive manner in section 7.3.1.

53 In this regard, Malina is supported inter alia by Polanyi et al (1957:33), Polanyi (1977:53), Ohnuki-Tierny (1981:16), Hollenbacb (1985:153; 1987:52), Pilcb (1985:146; 1988b:61), Horsley (1989b:4-5), Smith (1989:22), Oakman (1991a:34-35), Van Aarde (1991a:699) and Van Eck (1991 a:665).

54 The importance of this contribution by Malina 'lies in the fact that it sensitizes the interpreter to the fact that the society being studied was configurated radically different from ours (Van Staden 1991:56). According to Van Staden, therefore, the interpreter should therefore take extreme care not to be ethnucentrically anachronistic' (Van Staden 1991:56; my emphasis).

55 In a certain sense, this is a reaarkable statement by Myers, especially as it is understood against the background of Myers' reading of Mark in general. It is, however, clear that the implications of this insight of Myers is not taken into consideration in his own reading of the Gospel.

56 The terms emics and etics will be discussed in full in section 4.1.3. 